\title{
Elemental composition, metabolic activity and growth of Antarctic krill Euphausia superba during winter
}

\author{
Mark E. Huntley ${ }^{1}$, Walter Nordhausen ${ }^{1}$, Mai D. G. Lopez ${ }^{2}$ \\ ${ }^{1}$ Marine Biology Research Division, Scripps Institution of Oceanography, 0202, La Jolla, California 92093-0202, USA \\ ${ }^{2}$ Marine Science Institute, University of the Philippines, Diliman, Quezon City 1101, Philippines
}

\begin{abstract}
Euphausia superba Dana was collected at stations encompassing $3^{\circ}$ of latitude in icecovered waters west of the Antarctic Peninsula in winter of 1992 (July-August), and in the same region the previous summer (December-January). There was no significant change in any biometric index (dry weight vs length, carbon vs dry weight, nitrogen vs dry weight, or body $C: N$ ). Rates of ammonium excretion in winter were not significantly different from those previously reported for $E$. superba in summer. It was clear that E. superba fed as a carnivore in winter. Copepod body parts consistently occurred in krill guts. During winter shipboard experiments, freshly caught krill ingested copepods and produced faeces at rates comparable to those measured in summer. The low ratio of $N: P$ excretion (2.02) also suggests carnivorous feeding. A physiological model of carbon and nitrogen metabolism indicates that E. superba must feed during winter to maintain its observed C:N ratio and rate of ammonium excretion. On a diet of less than 1 Metridia gerlachei female copepod per day, a $20 \mathrm{~mm}$ krill can grow with a growth efficiency comparable to that achieved in summer. We suggest that starvation, body shrinkage and reduced metabolism are unusual behaviors for krill in winter, and that carnivory sustains growth until ice algae become available as food in late winter and early spring.
\end{abstract}

KEY WORDS: Krill · Winter $\cdot$ Carbon $\cdot$ Nitrogen $\cdot$ Metabolism $\cdot$ Excretion $\cdot$ Growth

\section{INTRODUCTION}

It has long been recognized that Euphausia superba feeds as a herbivore during the phytoplankton-rich periods of spring and summer in the ice-free regions of the Southern Ocean (Bargmann 1945, Marr 1962), when phytoplankton concentrations in the water column in coastal regions can be $>20 \mu \mathrm{g}$ chl $\mathrm{l}^{-1}$ (Holm-Hansen et al. 1989, Holm-Hansen \& Mitchell 1991). However, what it feeds on during the winter, when more than half its habitat is covered by ice (Zwally et al. 1983), and when phytoplankton concentrations are typically $<0.05 \mu \mathrm{g} \mathrm{chl} \mathrm{l}^{-1}$ (Morris \& Priddle 1984, Nöthig et al. 1992), is a matter of continuing controversy.

There are 2 schools of thought regarding the feeding, growth and metabolism of Euphausia superba during winter. The first of these assumes that feeding ceases, and that E. superba must reduce their metabolism, utilize stored energy, or even shrink in size. Ikeda \& Dixon (1982) pointed out that, even allowing for a considerable reduction in body lipid content (Raymont et al. 1971, Ferguson \& Raymont 1974, Clarke 1980), E. superba could not survive the entire winter on lipid stores alone. They purposely starved individuals ranging in size from 22.7 to $49.6 \mathrm{~mm}$ for $211 \mathrm{~d}$, found a significant reduction in body wet weight ( 32.1 to $56.1 \%$ ), and concluded that starvation and utilization of body protein was the only mechanism necessary to survive the winter. Similarly, Quetin \& Ross (1991) concluded that krill can survive the entire winter without feeding; they suggested that this is made possible primarily by a reduction in metabolic rate, and that body shrinkage accounts for only a small fraction (4\%) of the energy required for overwintering. Although Quetin \& Ross (1991) acknowledged that krill may feed on ice algae 
in other regions (e.g. Marschall 1988), they suggested that adults 'do not winter-over in the same way' (p. 59). Furthermore, they suggested that only multiyear ice may be able to sustain high ice algal concentrations and, because the ocean west of the Antarctic Peninsula is an area where only annual ice tends to occur, krill do not have the opportunity to feed on ice algae during the winter. Quetin \& Ross (1991) conclude that, in winter, 'adults do not feed, have lowered metabolic rates, and negative or zero growth rates' (p. 60).

These conclusions are at odds with observations allied to the second school of thought, which holds that krill do feed and grow in the winter. In situ observations of apparent feeding on ice algae by both larvae (Daly 1990) and adults (Stretch et al. 1988) have been confirmed by examination of gut pigments (Daly 1990) as well as by experiment (Marschall 1988). The guts of krill caught in the southern Scotia Sea in winter contained a variety of phytoplankton species (Lancraft et al. 1991), though it is not clear whether these were ice or water-column algae. Feeding on phytoplankton in the water column has also been observed in winter (Morris \& Priddle 1984); however, given the paucity of plant material, Morris \& Priddle concluded that 'it is unlikely that krill will rely completely on filter feeding throughout the year' (p. 57). Even for krill feeding on ice algae, Daly (1990) indicated that 'larvae must be obtaining carbon from heterotrophic and possibly detrital sources... in order to support the observed growth rate' (p. 1574).

Field observations strongly suggest that Euphausia superba continue to increase in length in winter, which implies growth. Such evidence can be found in Marr's (1962) data, reanalyzed by Rakusa-Suszczewski (1990), as well as in Stepnik's (1982) data in Admiralty Bay, reanalyzed by McClatchie (1988). If growth occurs during winter, but phytoplankton resources in both ice and the water column are inadequate, then $E$. superba must be able, as Daly (1990) concludes, to feed on either detritus or zooplankton. Feeding on detritus near the bottom has been observed in shallow regions (Kawaguchi et al. 1986), but this would not seem to be a viable mechanism over much of the Southern Ocean, where the depth of the water column generally exceeds the preferred depth of E. superba by hundreds or thousands of meters. Experiments conducted by Price et al. (1988) during the summer indicate that krill are able to ingest zooplankton, but they concluded that ingestion was insufficient to meet metabolic requirements. Copepods and other zooplankton have been consistently found among the gut contents of $E$. superba in summer (Hopkins 1985), autumn (Hopkins \& Torres 1989) and winter (Lancraft et al. 1991).

It is not clear how important carnivory might be for krill in winter, nor have measurements been made of various aspects of their metabolism at that time. In this article we present a set of shipboard observations on elemental composition, excretion, and feeding by Euphausia superba during midwinter (July-August 1992) made in coastal waters on the western side of the Antarctic Peninsula from Bransfield Strait in the north to Adelaide Island in the south. We compare these findings to similar measurements we made in the previous summer (December 1991-January 1992) in the same region.

\section{METHODS}

Collection of specimens. Live specimens were collected in Gerlache Strait, Crystal Sound, and points between, west of the Antarctic Peninsula between 6 July and 16 August 1992 (Fig. 1); in the summer (3 December 1991 to 10 January 1992) specimens were collected in Gerlache Strait. A $1 \mathrm{~m}$ ring net equipped with $110 \mu \mathrm{m}$ mesh and a $15 \mathrm{l}$ protected cod end (Reeve 1981) was typically deployed through an ice-free area alongside the ship. Vertical tows from a depth of approximately $100 \mathrm{~m}$ were made slowly (ca $10 \mathrm{~m}$ $\mathrm{min}^{-1}$ ) to minimize damage to the organisms. Specimens were transferred to filtered seawater maintained at ambient seawater temperature $\left(-0.5 \pm 1^{\circ} \mathrm{C}\right)$, sorted within $1 \mathrm{~h}$ after collection, and immediately used in subsequent experiments or prepared for analysis.

Excretion rates. Rates of ammonium and phosphate excretion were measured using water bottle methods

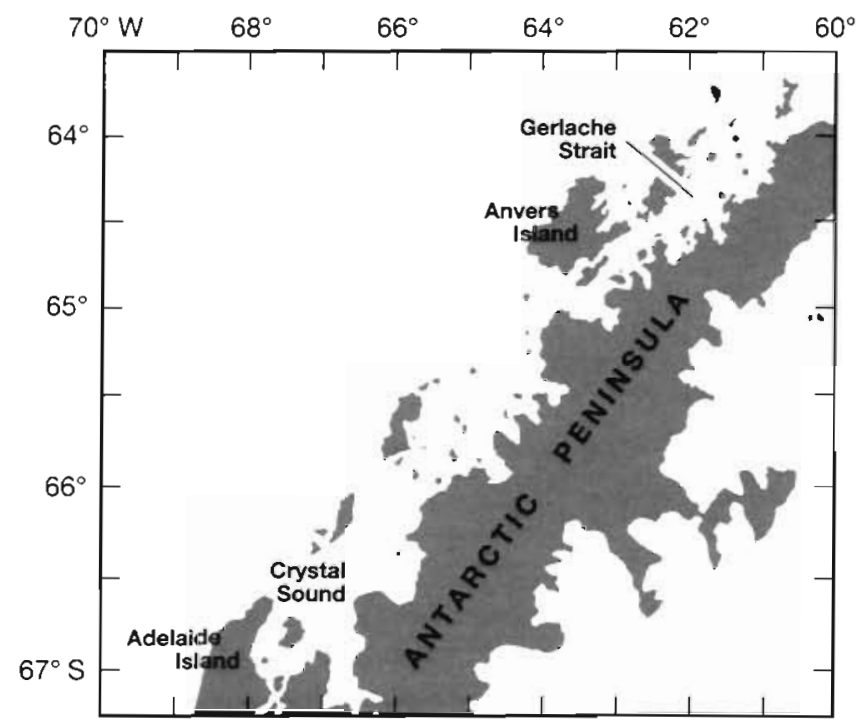

Fig. 1. Study area in the coastal region west of the Antarctic Peninsula, showing stations where Euphausia superba was collected for measurements of excretion, feeding and morphometry during July and August 1992 
(Omori \& Ikeda 1984). We conducted these experiments only with individuals collected during winter. All glassware was washed in $10 \% \mathrm{HCl}$ and then thoroughly rinsed with deionized water prior to use in experiments. Preliminary experiments were conducted to determine the appropriate combination of stocking density, container size, and experimental duration that would yield reproducible results and minimize experimental artifacts. Results showed that excretion rates remained linear over a period of $24 \mathrm{~h}$, and that clearly detectable values could be obtained from a single individual.

All experiments were begun immediately after sorting from net tows, and were conducted in the dark at $-0.5 \pm 0.5^{\circ} \mathrm{C}$ with individual Euphausia superba incubated in $500 \mathrm{ml}$ polypropylene jars filled with filtered seawater obtained from depths where $\mathrm{NH}_{4}{ }^{+}$and $\mathrm{PO}_{4}{ }^{-}$ concentrations were near the limits of detection. In order to minimize contamination, specimens were washed gently 3 times in filtered seawater prior to placing them in experimental containers. Initial samples were taken in duplicate from each container at the beginning of an experiment, as were final samples after ca $24 \mathrm{~h}$ of incubation. Control containers (without krill) were treated in the same fashion. When the experiment was completed krill were removed, their length measured and immediately frozen at $-80^{\circ} \mathrm{C}$ for later morphometric analyses. Chemical analyses were conducted within a few hours after each experiment. Phosphate and ammonium concentrations were determined using molybdate and phenol-hypochlorite methods, respectively (Strickland \& Parsons 1972). Standards were prepared daily.

Egestion rate. Immediately after collection and sorting, individuals were placed in $1 \mathrm{l}$ polypropylene jars containing $\mathrm{GF} / \mathrm{C}$-filtered seawater and incubated at $-0.5 \pm 0.5^{\circ} \mathrm{C}$ for periods of up to $24 \mathrm{~h}$ in the dark. After time intervals as short as $15 \mathrm{~min}$, individuals were transferred to a new container of freshly filtered seawater. Water from the first container, containing the faeces produced during the prior interval, was then filtered through a precombusted $\mathrm{GF} / \mathrm{C}$ filter. The filter was placed in a petri dish and frozen at $-80^{\circ} \mathrm{C}$ for later CHN analysis on a Perkin Elmer 2400 elemental analyzer. At the end of the experiment, individual krill were measured for body length and then frozen at $-80^{\circ} \mathrm{C}$. Egestion rate measurements were performed in both summer and winter.

Carnivorous feeding. At several stations during the winter cruise, Oithona spp. and Oncaea spp. collected by vertical net tows were added to filtered seawater and transferred to experimental containers. To estimate the initial number of copepods in the chambers, duplicate samples of initial prey suspensions were preserved in $5 \%$ buffered formalin for later microscopic analysis. Individual Euphausia superba, also collected from vertical net tows, were gently washed in filtered seawater and added to the experimental containers already containing the copepods. Experimental and control (without krill) containers were incubated at $-0.5 \pm 0.5^{\circ} \mathrm{C}$ for periods of up to $24 \mathrm{~h}$. At the end of the experiment, krill were removed for morphometric analyses and samples of remaining copepod prey were preserved in $5 \%$ buffered formalin. Analysis of the preserved samples allowed us to determine the number of copepod prey ingested in each experiment. We investigated the effect of container size by conducting our first experiments in containers of 2 sizes, 1 and $10 \mathrm{l}$. Analysis showed no significant difference in results, so subsequent experiments were carried out in 11 containers only.

Morphometry. During winter, individual Euphausia superba from excretion or feeding experiments were used for morphometric analysis. During summer, fresh specimens were obtained from net tows and immediately prepared for these analyses. Body length of fresh specimens was measured from the tip of the rostrum to the tip of the telson, excluding setae, to the nearest $\mathrm{mm}$. Deep-frozen $\left(-80^{\circ} \mathrm{C}\right)$ specimens were transported to the laboratory, where they were dried to constant weight in $<48 \mathrm{~h}$ at $50^{\circ} \mathrm{C}$ (Lovegrove 1962) and then maintained in a desiccator until whole animal dry weights were measured to the nearest $0.1 \mathrm{mg}$ on a microbalance. To prepare for CHN analysis, individual krill were homogenized using a ceramic mortar and pestle. An aliquot of the homogenized tissue was weighed to the nearest $0.001 \mathrm{mg}$ on a Cahn 31 electrobalance and then analyzed for carbon and nitrogen content using a Perkin Elmer 2400 elemental analyzer; acetanilide was used as the standard.

\section{RESULTS}

\section{Morphometry}

The relation between dry weight and body length for Euphausia superba in winter was indistinguishable from that for krill collected in summer (Table 1, Fig. 2). Furthermore, our measurements agree with those of Morris et al. (1988) for krill collected during summer, whose regression line we have overlaid on our data (Fig. 2). The extremes of our data set are represented by an individual of $15 \mathrm{~mm}$ body length with a dry weight of $2.73 \mathrm{mg}$, and a $47 \mathrm{~mm}$ krill with a dry weight of $198.1 \mathrm{mg}$. The specimens we analyzed in summer were generally smaller than those collected in winter.

Similarly, we found no difference between summer and winter relationships of body carbon to dry weight or body nitrogen to dry weight (Fig. 3). Percentage body carbon and nitrogen on dry weight tended to increase 
with body dry weight in both summer and winter specimens (Fig. 4). For individuals < $30 \mathrm{mg}$ dry wt, carbon was 30 to $35 \%$ of dry weight; it increased asymptotically to $40-45 \%$ of dry weight for individuals $>100 \mathrm{mg}$ dry wt. Although there was more scatter in the nitrogen data, smaller individuals tended to have 6 to $7 \%$ of their dry weight as nitrogen, whereas specimens $>100 \mathrm{mg}$ dry wt were more than $8 \%$ nitrogen. The percentages of body carbon and nitrogen tended to increase with body size, but the elemental ratio of carbon to nitrogen remained stable at a value of 4.76 ( $\mathrm{SD}=0.51$; Fig. 5).

\section{Excretion rates}

The rate of ammonium excretion by Euphausia superba in winter ranged from 0.093 to $2.66 \mu \mathrm{g} \mathrm{NH}_{4}{ }^{+} \mathrm{N}$ $\mathrm{h}^{-1}$ for individuals ranging from 6.4 to $145.1 \mathrm{mg}$ dry wt (Fig. 6). The excretion rate of ammonium-nitrogen represents $0.9 \%$ of body $\mathrm{N} \mathrm{d}^{-1}$ for a $10 \mathrm{mg}$ dry wt individual, and declines to $<0.5 \%$ of body $\mathrm{N} \mathrm{d}^{-1}$ for a $100 \mathrm{mg}$ dry wt individual (Fig. 7). The excretion rate of phosphorus ranged from 0.21 to $2.04 \mu \mathrm{gO}_{4}^{-}-\mathrm{P} \mathrm{h}^{-1}$ for individuals ranging from 7.4 to $93.1 \mathrm{mg}$ dry wt (Fig. 8).

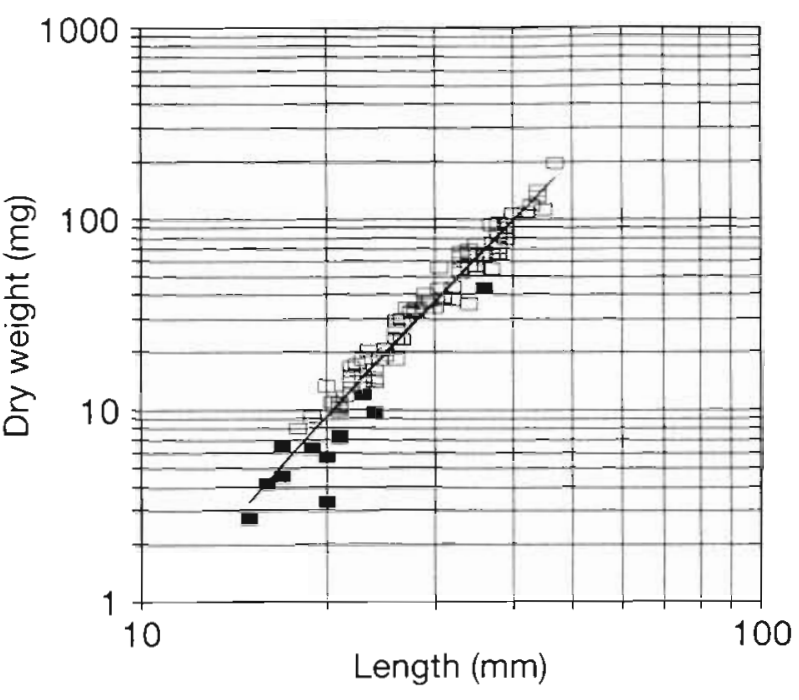

Fig. 2. Euphausia superba. Dry weight as a function of body length from tip of rostrum to tip of telson in summer (a) and winter $(\square)$. The regression line is for krill collected in summer (Morris et al. 1988). For regression equation for our data see Table 1
Table 1. Euphausia superba. Regression statistics for morphometrics, ammonium and phosphate excretion. L: body length $(\mathrm{mm})$; DW: dry weight (mg); BC: body carbon (mg); BN: body nitrogen $(\mathrm{mg})$; $\mathrm{X}$ : ammonium excretion ( $\mu \mathrm{g} \mathrm{N} \mathrm{h}{ }^{-1}$ ); $\mathrm{P}$ : phosphate excretion ( $\left.\mu \mathrm{g} \mathrm{P} \mathrm{h}^{-1}\right)$

\begin{tabular}{|c|c|c|c|}
\hline & $\mathrm{n}$ & $\log y=\log a+b \log x$ & I \\
\hline \multicolumn{4}{|c|}{ Winter (Jul-Aug 1992) } \\
\hline \multicolumn{4}{|c|}{ Morphometrics } \\
\hline DW vs $L$ & 83 & $\log \mathrm{DW}=-3.250+3.270 \log \mathrm{L}$ & 0.979 \\
\hline L vs DW & 83 & $\log \mathrm{L}=1.014+0.293 \log \mathrm{DW}$ & 0.979 \\
\hline BC vs DW & 79 & $\log \mathrm{BC}=2.457+1.083 \log \mathrm{DW}$ & 0.997 \\
\hline DW vs $B C$ & 79 & $\log \mathrm{DW}=0.508+0.917 \log \mathrm{BC}$ & 0.996 \\
\hline BN vs DW & 79 & $\log B N=1.033+1.858 \log \mathrm{DW}$ & 0.996 \\
\hline$D W$ vs $B N$ & 79 & $\log \mathrm{DW}=1.109+0.961 \log \mathrm{BN}$ & 0.996 \\
\hline \multicolumn{4}{|c|}{ Ammonium excretion } \\
\hline X vs DW & 75 & $\log X=-1.273+0.744 \log D W$ & 0.762 \\
\hline$X$ vs $B C$ & 75 & $\log X=-0.887+0.676 \log B C$ & 0.748 \\
\hline$X$ vs NN & 75 & $\log X=-0.461+0.739 \log B N$ & 0.787 \\
\hline \multicolumn{4}{|c|}{ Phosphate excretion } \\
\hline P vs DW & 36 & $\log P=-1.249+0.735 \log D W$ & 0.796 \\
\hline Pvs BC & 32 & $\log P=-2.722+0.629 \log B C$ & 0.754 \\
\hline$P$ vs BN & 32 & $\log P=-2.518+0.698 \log B C$ & 0.773 \\
\hline \multicolumn{4}{|c|}{ Summer (Dec 1991 - Jan 1992) } \\
\hline \multicolumn{4}{|c|}{ Morphometrics } \\
\hline DW vs $L$ & 13 & $\log D W=-2.909+2.866 \log L$ & 0.924 \\
\hline L vs DW & 13 & $\log \mathrm{L}=1.057+0.298 \log \mathrm{DW}$ & 0.924 \\
\hline BC vs DW & 13 & $\log \mathrm{BC}=-0.536+1.056 \log \mathrm{DW}$ & 0.994 \\
\hline DW vs C & 13 & $\log D W=50.512+0.935 \log B C$ & 0.994 \\
\hline $\mathrm{BN}$ vs $\mathrm{DW}$ & 13 & $\log \mathrm{BN}=-1.222+1.081 \log \mathrm{DW}$ & 0.992 \\
\hline DW vs BN & 13 & $\log \mathrm{DW}=1.126+0.911 \log \mathrm{BN}$ & 0.992 \\
\hline
\end{tabular}

\section{Egestion rate}

Rates of faecal production by freshly caught field specimens of 24 to $28 \mathrm{~mm}$ body length were 0.28 and $0.38 \mu \mathrm{g} \mathrm{C}$ $\mathrm{h}^{-1}$ during the first hour after capture in 2 separate experiments utilizing 7 and 6 krill, respectively (Fig. 9). Ratios of C:N in faeces of Euphausia superba showed no significant difference between summer and winter (Table 2); the ratio in summer was 11.8 and the winter ratio was 14.2 .

\section{Carnivorous feeding}

Krill ranging from 18 to $42 \mathrm{~mm}$ body length exposed to freshly caught copepods, dominated by Oncaea and Oithona spp., ingested as many as several hundred individuals per day (Table 3). Ingestion rates varied from 44-356 copepods $\mathrm{d}^{-1}$ for $18-23 \mathrm{~mm}$ krill to $33-476$ copepods $d^{-1}$ for $37-42$ $\mathrm{mm}$ individuals. No differences in ingestion rate were detected between experimental containers of 1 or $10 \mathrm{l}$, each with single krill predators. How- 


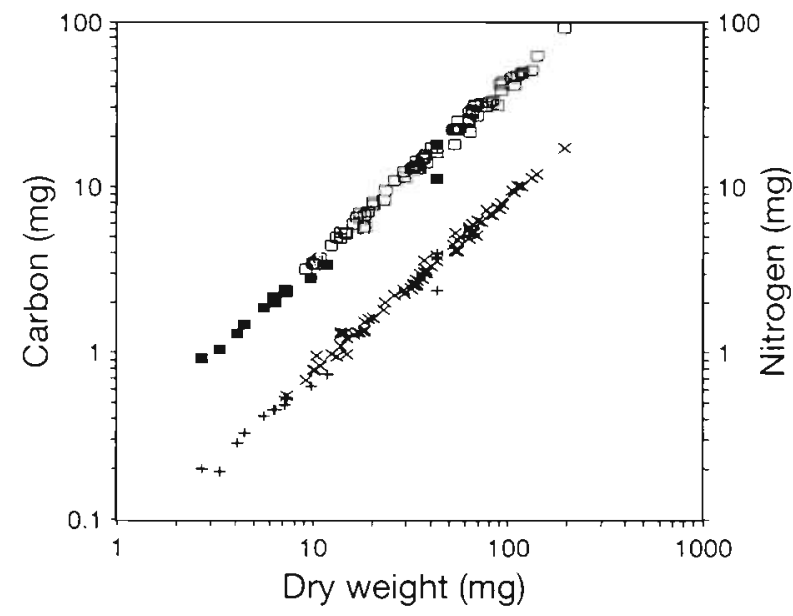

Fig. 3. Euphausia superba. Body carbon in summer (a) and winter $(\square)$, and body nitrogen in summer $(+)$ ard winter $(x)$ as a function of dry weight. Regression equations in Table 1
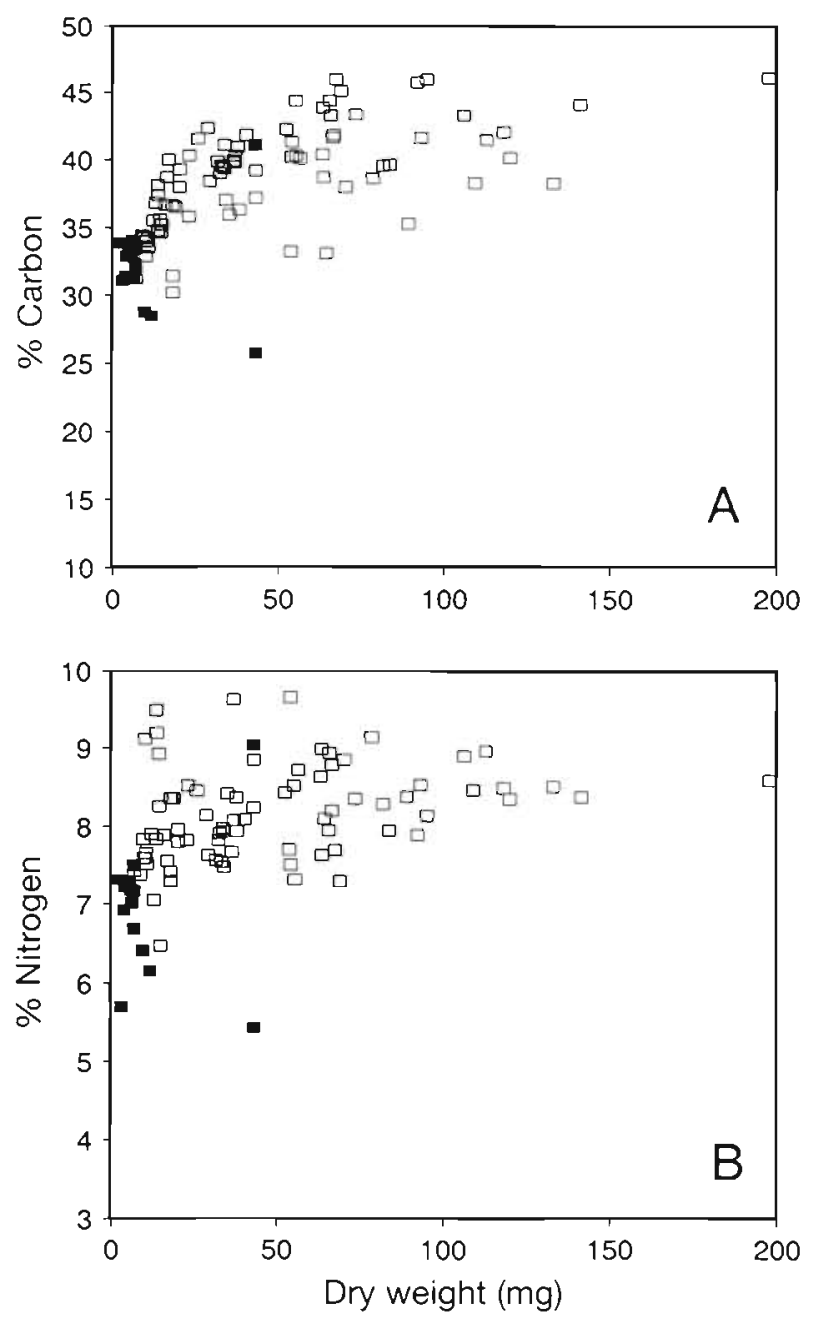

Fig. 4. Euphausia superba. (A) Body carbon and (B) body nitrogen as a percentage of dry weight in summer $(\boldsymbol{a})$ and winter $(\square)$ as a function of dry weight
Table 2. Euphausia superba. Ratios of C: $\mathrm{N}$ in krill faeces collected during the first $6 \mathrm{~h}$ after capture. $\bar{x}$ : mean; SD: standard deviation; $n$ : number of measurements

\begin{tabular}{|lccc|}
\hline & $\bar{x}$ & SD & $\mathrm{n}$ \\
\hline $\begin{array}{l}\text { Summer } \\
\text { Nov 1989 }\end{array}$ & 11.8 & 2.85 & 31 \\
$\begin{array}{l}\text { Winter } \\
\text { Jul-Aug 1992 }\end{array}$ & 14.2 & 6.6 & 72 \\
\hline
\end{tabular}

Table 3. Euphausia superba. Feeding rates of 4 size classes measured in laboratory experiments. Daily consumption of small copepods (Oithona spp. and Oncaea spp.) are presented as mean $(\bar{x})$, standard error (SE), and range (Min. and Max.)

\begin{tabular}{|lcrrrr|}
\hline \multirow{2}{*}{$\begin{array}{l}\text { Length } \\
(\mathrm{mm})\end{array}$} & $\begin{array}{c}\text { Dry weight } \\
(\mathrm{mg})\end{array}$ & \multicolumn{4}{c|}{$\begin{array}{c}\text { Ingestion rate } \\
\text { (copepods krill-1 }\end{array}$} \\
& & $\bar{x}$ & SE & Min. & Max. \\
\hline $18-23$ & $6.5-16.9$ & 177 & 105 & 44 & 356 \\
$24-27$ & $17.0-29.9$ & 183 & 99 & 46 & 411 \\
$28-36$ & $30.0-69.9$ & 182 & 136 & 45 & 641 \\
$37-42$ & $70.0-115.9$ & 243 & 165 & 33 & 476 \\
\hline
\end{tabular}

ever, ingestion rates were greatest during the first hour and declined rapidly thereafter, suggesting that satiation may have occurred.

\section{DISCUSSION}

\section{Morphometric indices}

The relation between dry weight and body length for both summer and winter animals (Fig. 2) did not differ significantly from relations reported elsewhere (Kato et al. 1982, Morris et al. 1988). We found no significant differences between the summer and winter relationships of body carbon to dry weight or body nitrogen to dry weight (Fig. 3).

Percentage of body carbon and nitrogen tended to increase as a function of dry weight (Fig. 4). For specimens in the size range 2.7 to $30 \mathrm{mg}$ dry wt we found $34.8 \%$ carbon and $7.64 \%$ nitrogen; for those in the size range 30 to $198 \mathrm{mg}$ dry wt we found $40.3 \%$ carbon and $8.23 \%$ nitrogen. The data for large specimens are consistent with previous reports; however, our nitrogen content data - in both summer and winter - are slightly lower than previously reported (Table 4). It is apparent that these differences are caused primarily by specimens of $<10 \mathrm{mg}$ dry wt. To our knowledge, juvenile specimens 


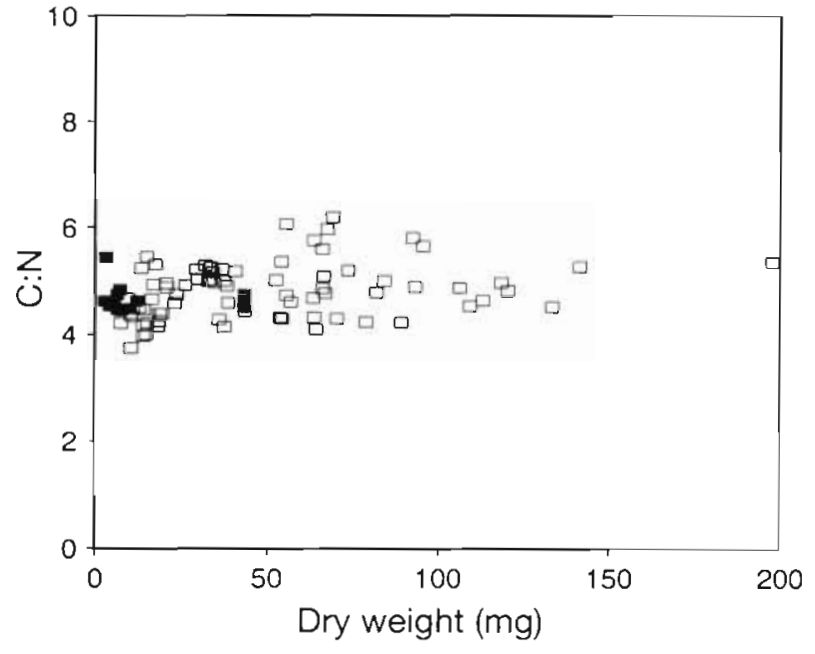

Fig. 5. Euphausia superba. Body C:N ratio in summer (a) and winter ( $\square$ ) plotted against dry weight

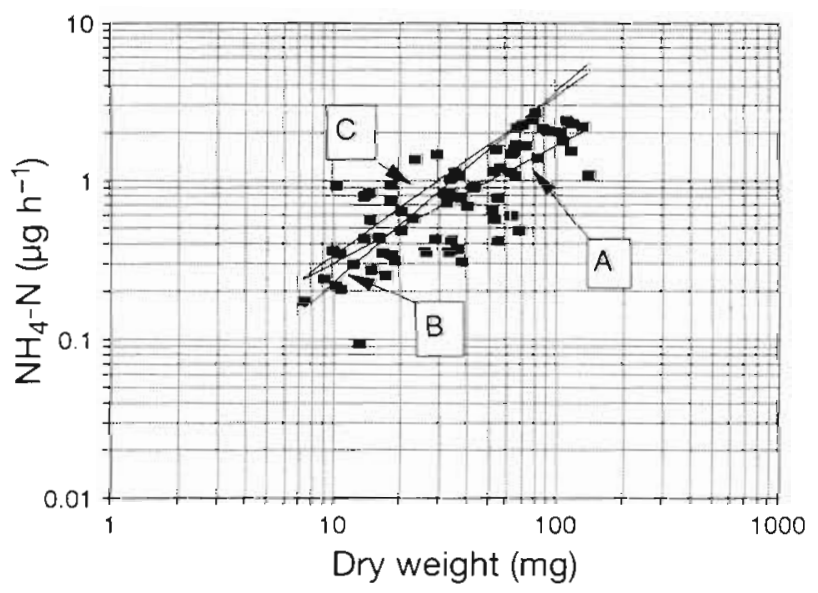

Fig. 6. Euphausia superba. Excretion rate of ammoniumnitrogen in winter as a function of body dry weight. A: regression line for the data shown here; $B$ : regression line based on summer data reported by Segawa et al. (1982); C: regression line based on summer data reported by Ikeda \& Mitchell (1982)

Table 4. Euphausia superba. Comparison to published values of carbon and nitrogen content as percentage of dry weight, and mean $\mathrm{C}: \mathrm{N}$ ratios according to size class. na: not applicable (values of percentage carbon and nitrogen are not given for the complete data set reported in this paper because these vary with dry weight; see Fig. 4)

\begin{tabular}{|lcccl|}
\hline Dry wt (mg) & $\% \mathrm{C}$ & $\% \mathrm{~N}$ & $\mathrm{C}: \mathrm{N}$ & Source \\
\hline $47-243$ & 43.9 & 10.8 & 4.06 & Ikeda \& Bruce (1986) \\
$50-200$ & 39.9 & 12.1 & 3.31 & Ikeda \& Kirkwood (1989) \\
$27-354$ & 46.6 & 10.2 & 4.59 & Ikeda \& Mitchell (1982) \\
Larvae & 44.2 & 9.88 & 4.43 & Ikeda (1984) \\
$2.7-30$ & 34.8 & 7.64 & 4.59 & This study \\
$30-198$ & 40.3 & 8.23 & 4.91 & This study \\
$2.7-198$ & na & na & 4.76 & This study \\
\hline
\end{tabular}

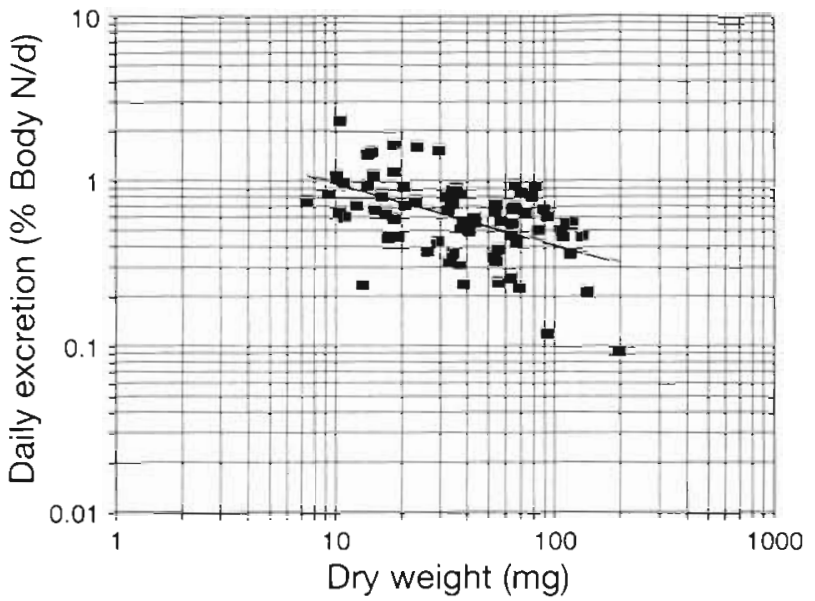

Fig. 7. Euphausia superba. Daily utilization of body nitrogen in the form of ammonium-nitrogen in winter as a function of body dry weight

of $<10 \mathrm{mg}$ dry wt caught in nature have never been analyzed for carbon and nitrogen content (cf. Ikeda 1981, Ikeda \& Mitchell 1982, Ikeda \& Bruce 1986)

The body $\mathrm{C}: \mathrm{N}$ ratio did not change significantly with season; in summer it was $4.64(\mathrm{SD}=0.25)$, and in winter it was $4.79(\mathrm{SD}=0.51)$; on average, these values are only slightly greater than those reported by $T$. Ikeda and co-workers, which range from 3.31 to 4.59 (Table 4). The values we measured would not be consistent with starvation; $\mathrm{C}: \mathrm{N}$ ratios of starving Euphausia superba decreased from 4.1 to 3.9 in the laboratory (Ikeda \& Dixon 1982).

\section{Excretion rates}

We found little difference between summer and winter rates of ammonium excretion. By comparison to 2 sets of measurements made in summer (Segawa et al. 1982, Ikeda 1984), the rates we measured appear to be higher or approximately the same for smaller individuals (ca $10 \mathrm{mg}$ dry wt), and almost $50 \%$ lower for individuals of $>100 \mathrm{mg}$ dry wt (Fig. 6). However, differences between the 3 sets of data are not statistically significant. Expressed as a function of body nitrogen, winter ammonium excretion is well within the range reported for Euphausia superba in summer. Daily nitrogen excretion ranged from 0.9 to $0.5 \%$ body $\mathrm{N} \mathrm{d}^{-1}$ for specimens ranging in size from 10 to $100 \mathrm{mg}$ dry wt (Fig. 7). Published data for krill collected in spring and summer are in the same range, indicating a daily metabolic loss of body nitrogen of $0.28 \%$ (Ikeda \& Bruce 1986), 


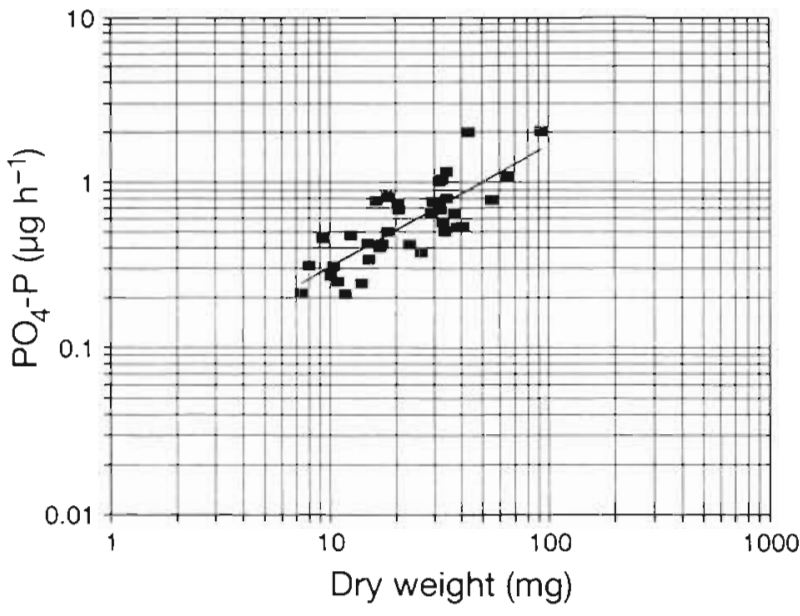

Fig. 8. Euphausia superba. Excretion rate of phosphatephosphorus in winter as a function of body dry weight

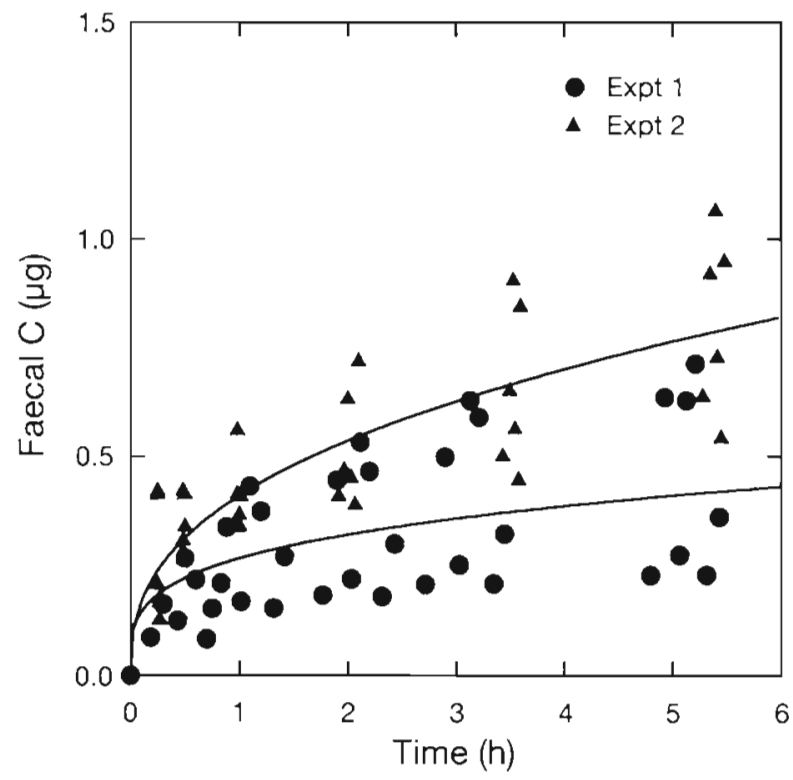

Fig. 9. Euphausia superba. Egestion rate of faecal carbon by individuals freshly collected from the field in winter and maintained for $6 \mathrm{~h}$ on board ship. Data shown are from 2 separate experiments

$0.40 \%$ (Ikeda \& Kirkwood 1989) and $0.81 \%$ (Ikeda \& Mitchell 1982), with loss rates being greatest for small individuals (Ikeda \& Kirkwood 1989), just as in our data set.

Excretion of phosphate reflects the feeding history of marine zooplankton (Butler et al. 1970) and, in Euphausia superba, increases when the diet is dominated by microcrustaceans rather than by phytoplankton (Ikeda \& Dixon 1982). Excretion rates in winter averaged $0.026 \mu \mathrm{g} \mathrm{P} \mathrm{mg}^{-1}$ dry $\mathrm{wt} \mathrm{h}^{-1}$, which is more than double that reported for animals measured in the summer (Ikeda \& Dixon 1982, Ikeda \& Kirkwood 1989).

It is interesting to compare our measurements with those of starving individuals, since it has been suggested that Euphausia superba may starve so severely in the absence of food that they should shrink in size in winter (Ikeda \& Dixon 1982), or even in summer (Nicol et al. 1992). The atomic N:P ratio we measured was 2.02 ( $\mathrm{SD}=0.96)$. This is lower than the mean value of 15.3 reported by Ikeda \& Mitchell (1982) or the mean value of 5.35 (Ikeda \& Kirkwood 1989) for E. superba in the same size range as the animals we measured. Similarly low N:P ratios have been reported for various species of copepods (Le Borgne 1986). By comparison to the results of Ikeda \& Dixon (1982), our data suggest a carnivorous diet. They conducted an experiment in which one set of krill were starved for $211 \mathrm{~d}$, a second set were fed phytoplankton, and a third set were fed frozen copepods and Tetra-Marin. The highest N:P ratio was obtained from starved individuals, and the lowest from those on the carnivorous diet.

\section{Feeding in winter}

Several lines of evidence point to active feeding by Euphausia superba in winter. First, we observed that krill guts contained recognizable body parts of copepods (V. Øresland unpubl. data). This is not a new observation for krill in winter (Marr 1962, Pavlov 1969, Lancraft et al. 1991). The guts of freshly collected specimens were usually white in color, rather than green as is commonly observed in summer when phytoplankton abundance is high; after a day or two in filtered seawater the guts became clear and faeces accumulated in the container. Second, krill placed in filtered seawater immediately after capture produced faecal carbon and nitrogen at rates high enough (ca $0.33 \mathrm{mg} \mathrm{C}$ ind.$^{-1} h^{-1}$ ) to suggest a ration exceeding $15 \%$ body weight daily. This is approximately the same as the values measured in summer (Clarke et al. 1988, Nordhausen \& Huntley 1990). The third piece of evidence for carnivorous feeding is direct observation. Krill placed in 1 or $10 \mathrm{l}$ chambers containing recently captured Oithona and Oncaea spp. removed significant numbers of copepods in several hours (Table 3 ).

We do not believe that any of our results could be attributed to feeding in the net or the cod end, although the mesh size we used $(110 \mu \mathrm{m})$ was small enough to capture copepod prey. Net tows were $<15 \mathrm{~min}$, so the average individual would have spent $<8 \mathrm{~min}$ in the net. Many of the fresh specimens contained material in the midgut and hindgut as well as in the foregut, and most of the crustacean remains in the gut consisted of mandibles. It seems improbable that 
Euphausia superba could have filled their guts, from foregut to hindgut, with almost completely digested material in less than 15 min.

Taken alone, any one of the observations we report here might be looked upon as equivocal evidence of active feeding and metabolism by Euphausia superba in winter. However, taken together, the relatively high body $\mathrm{C}: \mathrm{N}$ ratio, low $\mathrm{N}$ : P ratio, rates of ammonium and phosphate excretion, rates of faecal production, and the similarity in summer and winter biometric indices overwhelmingly point to the conclusion that $E$. superba was not 'hibernating', but rather must have been metabolically and trophically active throughout the winter. Concentrations of phytoplankton were consistently low in the water column $\left(<0.05 \mu \mathrm{g} \mathrm{chl} \mathrm{l}^{-1}\right)$, as well as in a number of ice cores taken throughout the area we surveyed (W. Cochlan pers. comm.). Although the ocean was usually covered by ice, the ice was white rather than green, as has been observed elsewhere (Daly 1990); this confirms the observation of Stretch et al. (1988) that sea ice discolored by microalgae did not occur from May through August 1985 in waters west of the Antarctic Peninsula. Under-ice video observations using an ROV did not reveal the significant accumulation of krill that has sometimes been observed there (e.g. Marschall 1988). Microheterotrophs could be a source of food in winter. However, the ratio of particulate chlorophyll to ATP measured throughout our survey area, in both 2 to $20 \mu \mathrm{m}$ and 20 to $200 \mu \mathrm{m}$ size fractions, was identical to the values measured in summer (D. M. Karl unpubl. data); since chlorophyll was 2 orders of magnitude lower in abundance, the same would therefore have been true of the microheterotrophic biomass, which is relatively low even in summer (Karl et al. 1991a). We conclude that krill were actively feeding in winter throughout the Antarctic Peninsula coastal region, and that the major source of available food was zooplankton.

\section{Alternative models of Euphausia superba winter physiology}

It has been suggested that, in an evolutionary sense, krill have adopted an overwintering strategy that involves a reduction in ingestion rate, perhaps accompanied by a reduction in metabolism, which together result in negative growth that manifests itself as body shrinkage (Ikeda \& Dixon 1982, Quetin \& Ross 1991) There is abundant evidence of reduced feeding on phytoplankton in winter (e.g. Morris \& Priddle 1984). However, reports of crustacean remains in krill gut contents (Marr 1962, Pavlov 1969, Lancraft et al. 1991), observations of feeding on under-ice algae during late winter (Marschall 1988, Stretch et al. 1988), and the laboratory demonstration of Euphausia superba's ability to feed on copepods (Price et al. 1988) suggest that krill might not be forced to suspend feeding for the entire winter. The evidence for reduced metabolism is based on measurements of respiration in winter (Quetin \& Ross 1991); the authors concluded that more than $70 \%$ of anticipated energy requirements could be satisfied merely by a reduction in respiration.

There is ample evidence that Euphausia superba responds to starvation by shrinking in size with successive molts. In the laboratory this phenomenon can manifest itself in a few weeks (Nicol et al. 1992), and may persist for more than 6 mo (Ikeda \& Dixon 1982). However, the evidence for individual body shrinkage in field populations of euphausiids (Falk-Petersen 1985, McClatchie et al. 1991) is at least as equivocal as the evidence for growth during winter (Daly 1990).

\section{Model description and assumptions}

We used a physiological model which parameterizes ingestion, egestion, assimilation efficiency, respiration, excretion and growth. We specified as model inputs the rates of respiration and excretion, with the latter being taken from the measurements reported here (Table 1 , Fig. 6). The model is initialized in mid-April, by which time primary production in coastal waters of the Antarctic Peninsula has fallen by 2 orders of magnitude relative to the spring-summer maximum (Holm-Hansen \& Mitchell 1991), and is executed in daily time steps until it terminates in mid-August - the approximate time of our winter observations. We introduced model krill of 3 sizes: 20,30 and $40 \mathrm{~mm}$ in length; or $9.5,38.1$ and $101.8 \mathrm{mg}$ dry $\mathrm{wt}_{\text {; }}$ or $3.25,14.8$ and $43.2 \mathrm{mg} \mathrm{C}$, with a body C: $N$ ratio of 4.76 (Table 4 ). The 2 smaller sizes represent 2 dominant modes generally present in the krill population in mid-April in the Antarctic Peninsula region (Stepnik 1982, Brinton 1991).

We investigated 3 different scenarios. The first of these is proposed by the conclusion of Quetin \& Ross (1991) that, in winter, adult Euphausia superba west of the Antarctic Peninsula 'do not feed, and have lowered metabolism, and negative or zero growth rates' (p. 60). For this scenario we set the ingestion rate equal to zero and used the length-dependent winter respiration rate given by Quetin \& Ross (1991). The second scenario is essentially the same as the first. except that we used the weight-dependent respiration rate given by Ikeda \& Mitchell (1982), which is in close agreement with other published rates measured in summer (Chekunova \& Rynkova 1974, Segawa et al. 1982, Ikeda 1984, Rakusa-Suszczewski 1990). In both cases we evaluated the body length, dry weight, carbon and nitrogen, and compared the body $C: N$ 
ratio to that observed in late winter. In the third scenario, we required that the $C: N$ ratio remain constant throughout the winter, which is consistent with our observations (Table 4), and allowed the rates of ingestion and respiration to vary freely. We then compared model predictions of respiration to published values.

\section{The model}

The physiological equation for growth in terms of carbon $\left(G_{C}\right)$ is

$$
G_{C}=a_{C} I_{C}-R
$$

where $a_{C}=$ assimilation efficiency of $\operatorname{carbon}_{i} I_{C}=$ ingestion rate of carbon; and $R=$ rate of respiration. Similarly, for nitrogen, growth $\left(G_{N}\right)$ is expressed as

$$
G_{N}=a_{N} I_{N}-X
$$

where $a_{N}=$ assimilation efficiency of nitrogen; $I_{N}=$ ingestion rate of nitrogen; and $X=$ excretion rate of ammonium-nitrogen, which we presume with reasonable accuracy to account for all excretion of soluble nitrogen (Corner \& Davies 1971, Ikeda \& Dixon 1982, Le Borgne 1986).

A general equation for growth based on body weight can also be written as

$$
G=\frac{W_{t}-W_{0}}{t}
$$

where $W_{0}=$ initial body weight and $W_{t}=$ body weight at time $t$. In the model here we denote the carbon and nitrogen body weights as $C_{0}, C_{t}$, and $N_{0}, N_{t}$, respectively.

\section{Scenario 1: no ingestion, winter metabolism}

If, as Quetin \& Ross (1991) suggest, the ingestion rate of Euphausia superba is negligible, then its carbon weight after some period of winter would be

$$
C_{t}=C_{0}-R t
$$

and its nitrogen weight would be

$$
N_{t}=N_{0}-X t
$$

We took as the basis for the respiration rate, $R$, the winter metabolism reported by Quetin \& Ross (1991; their Fig. 6)

$$
\log R=0.0285 L-2.2258
$$

where $R$ is in $\mathrm{ml} \mathrm{O}_{2} \mathrm{~h}^{-1}$ and $L=$ body length in $\mathrm{mm}$, and converted it to units of carbon by the relation $1 \mathrm{mg} \mathrm{C}$ respired $=(12 / 22.4) \mathrm{ml} \mathrm{O}_{2}$ consumed (Omori \&
Ikeda 1984). Inclusion of a value for the respiratory quotient (RQ) would not have a significant effect on reducing respiration. The $R Q$ value for protein as metabolic substrate is 0.97 when ammonium is the excretory product, and 0.84 when urea is the excretory product; it is 0.72 when lipid is the metabolic substrate (Gnaiger 1983). Euphausia superba has insignificant amounts of body lipid (Clarke 1980) and, if it were starving, would likely utilize its body protein, with ammonium as the primary excretion product (Ikeda \& Dixon 1982). The appropriate value for RQ would be 0.97 , reducing our estimate of respiration by only $3 \%$, so we have ignored it.

We took as the basis for the excretion rate, $X$, the winter rate of ammonium excretion reported in this paper (Table 1), i.e.

$$
X=0.0533 W^{0.744}
$$

where the excretion rate is in $\mu \mathrm{g} \mathrm{N} \mathrm{h} \mathrm{N}^{-1}$ and $W=$ body dry wt in mg. Substituting the metabolic loss terms for carbon and nitrogen into Eqs. (4) \& (5) and converting to daily rates (i.e. $t=1$ ) yields the carbon and nitrogen weights at the end of each day. Reiteration over the 4 mo period beginning in mid-April yields the predicted carbon and nitrogen weights, as well as the $C: N$ ratio, in mid-August.

The relationships between body length, dry weight, and carbon in winter were identical to those measured in summer (Figs. $2 \& 3$ ). Thus, we used the predicted carbon weight to estimate dry weight from

$$
W=3.22 C_{t}^{0.916}
$$

and, in turn, used the resultant dry weight to estimate body length from

$$
L=10.33 W^{0.293}
$$

The results of this simple model (Fig. 10) show that body carbon, dry weight and length decline precipitously for all 3 model krill sizes, resulting in terminal shrinkage by early July at the latest. This result is independent of the nitrogen excretion rate, which causes body nitrogen to decline slowly. However, something is clearly wrong; either the 'winter' respiration rate reported by Quetin \& Ross (1991) is too high, or else krill would have to ingest enough carbon-rich food both to offset respiratory losses and to maintain a $\mathrm{C}: \mathrm{N}$ ratio in the observed range of approximately 4.5 to 5.0 .

\section{Scenario 2: no ingestion, summer metabolism}

In this case we used precisely the same approach as in the first scenario, the only exception being that we 

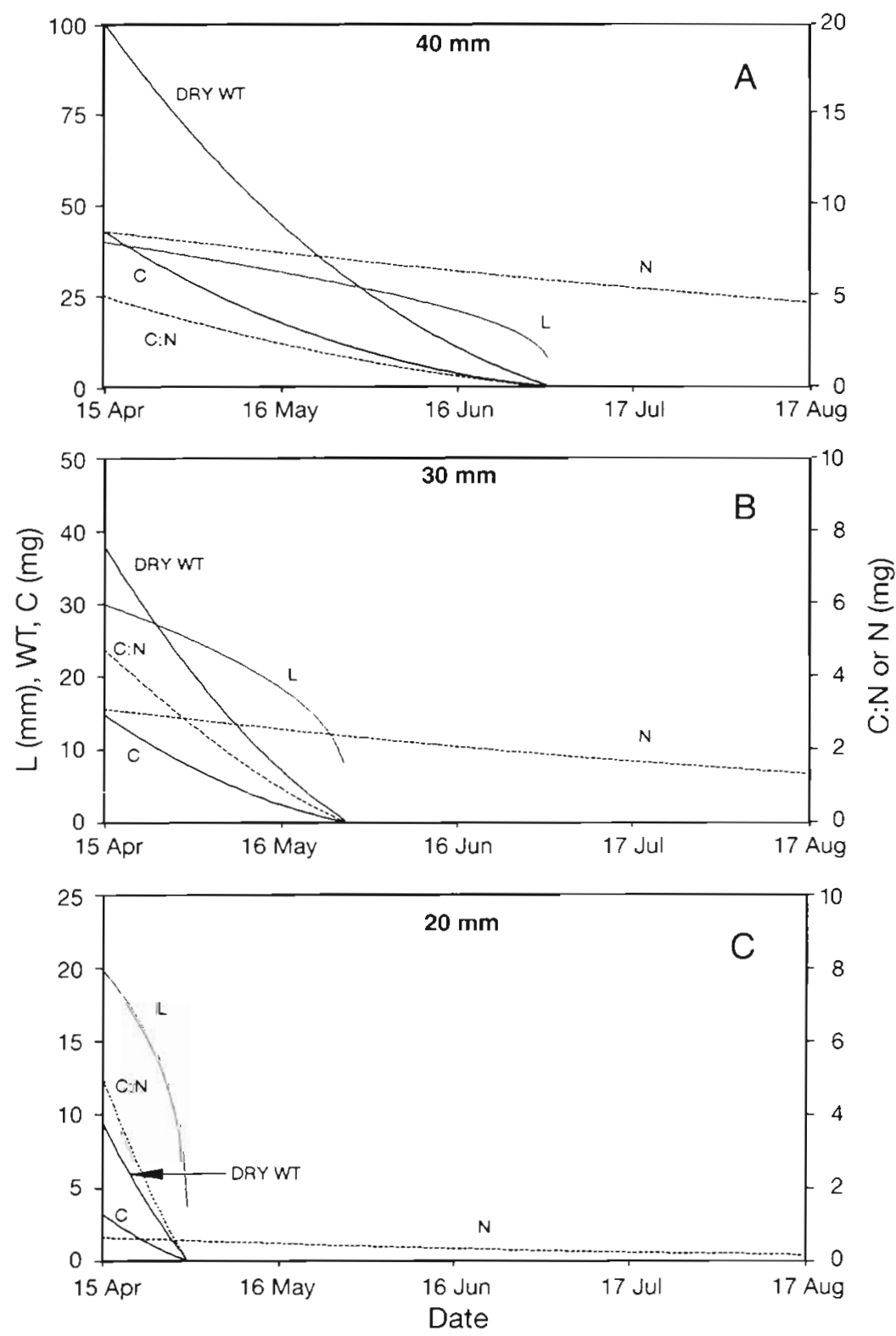

Fig. 10. Euphausia superba. Temporal change of body length, dry weight, carbon and nitrogen and $C: N$ ratio during 4 mo of winter for krill of (A) 40, (B) 30 . and (C) $20 \mathrm{~mm}$ length. Model assumes no ingestion and the winter respiration rate reported by Quetin \& Ross (1991)

calculated the respiration rate according to the relation given by Ikeda \& Mitchell (1982), where

$$
\log R=0.86 \log W-0.101
$$

where $R$ is in $\mu \mathrm{l} \mathrm{O}_{2} \mathrm{~h}^{-1}$ and the dry weight, $W$, is in $\mathrm{mg}$; oxygen consumption in $\mu \mathrm{l}$ was converted to carbon respiration in $\mu \mathrm{g}$, as for Eq. (6).

The results of using Ikeda \& Mitchell's (1982) respiration values (Fig. 11) are similar to those that would be obtained using the respiration rates reported by
Chekunova \& Rynkova (1974), Segawa et al. (1982), Ikeda (1984) and Rakusa Suszczewski (1990). The results are less surprising than those obtained using Quetin \& Ross' (1991) 'winter' metabolic rate, in that the model animals are able to survive 4 mo of winter without losing all body carbon (e.g. from 3.25 to $1.54 \mathrm{mg} \mathrm{C}$ for a $20 \mathrm{~mm} \mathrm{krill}$ ). Results are consistent with the prediction that nonfeeding krill should shrink in winter (Ikeda \& Dixon 1982). However, the one prediction that is at variance with observation is the $\mathrm{C}: \mathrm{N}$ ratio, which increases substantially (e.g. to 8.5 for a $20 \mathrm{~mm}$ individual). Slight increases in the C: $N$ ratio are to be expected for krill subjected to increasing, not decreasing, food availability (Ikeda \& Kirkwood 1989), but values predicted by this model scenario are much greater than ever reported for Euphausia superba (cf. Ikeda \& Mitchell 1982. Ikeda \& Bruce 1986).

One explanation for the high $\mathrm{C}: \mathrm{N}$ ratio is that our model overestimates losses of body nitrogen. However, if anything, metabolic nitrogen losses are underestimated by the model because we have assumed that ammonium is the sole nitrogenous excretory product. Ammonium accounted for $84 \%$ of total nitrogen excretion in Euphausia superba maintained in the laboratory (Ikeda \& Dixon 1982), which is similar to that reported for other zooplankton (Corner \& Davies 1971, Corner et al. 1976, Le Borgne 1986). If losses of organic nitrogen were included in the model, then the final $C: N$ ratio would be even higher.

Another explanation for the high $C: N$ ratio is that it is unrealistic because, in order to maintain a constant C: $\mathrm{N}$ ratio, krill must feed in winter. This possibility - acknowledged by Ikeda \& Dixon (1982), and supported by our observations - is investigated in the third model scenario.

\section{Scenario 3: ingestion in winter}

In this version of the model we have estimated various aspects of metabolism beginning with 2 simple assumptions based on observation. First, we assume that some ingestion must take place in winter, as evi- 

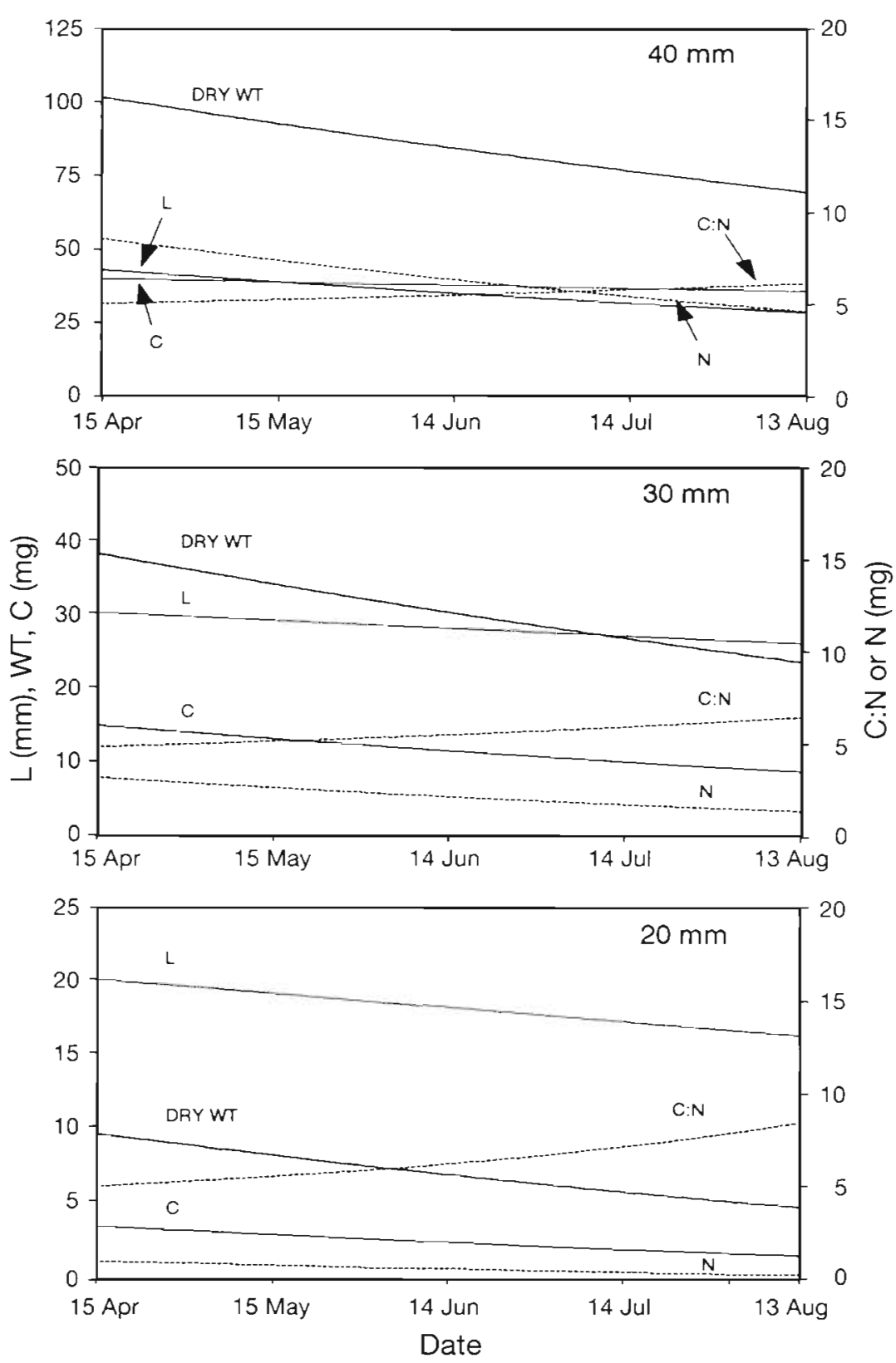

Fig. 11. Euphausia superba. Model predictions as for Fig. 10, also based on the assumption of no ingestion, but using the summer respiration rate reported by Ikeda \& Mitchell (1982)

denced by the production of faeces, the presence of crustacean body parts in the gut, and the observed ingestion of copepod prey. Second, we assume that the body $\mathrm{C}: \mathrm{N}$ ratio remains constant throughout the winter at the observed value of 4.76 (Table 4 ). From this second assumption it follows that the $\mathrm{C}: \mathrm{N}$ ratio of growth rates must also remain constant, i.e.

$$
\frac{C_{0}}{N_{0}}=\frac{C_{t}}{N_{t}}=\frac{G_{C}}{G_{N}}=4.76
$$

From observation we also know the $\mathrm{C}: \mathrm{N}$ ratio of egested faeces in winter (Table 2):

$$
\frac{E_{C}}{E_{\mathrm{N}}}=14.2
$$

and, if Euphausia superba is feeding on copepods in winter, then we may assume the value for the $\mathrm{C}: \mathrm{N}$ ratio of its food to be in the range:

$$
\frac{I_{\mathrm{C}}}{I_{\mathrm{N}}} \cong 9.0( \pm 2.0)
$$

In his review of copepod chemical composition, Båmstedt (1986) reported the mean body $\mathrm{C}: \mathrm{N}$ ratio of epipelagic boreal species to be ca 8.0 ( $\mathrm{n}=11$ ). No measurements appear to have been made of the $C: N$ ratio of Antarctic copepods in winter, but such measurements have been made in the Arctic. In summer, when lipid reserves are generally low, body $\mathrm{C}: \mathrm{N}$ ratios may be $<5.0$ (Ikeda \& Bruce 1986), but lipid-rich Arctic copepods may have C: $\mathrm{N}$ ratios $>9.0$ (Omori 1969, lkeda 1974). For lipid-storing Calanus finmarchicus females, the $\mathrm{C}: \mathrm{N}$ ratio increases from 4.9 in April to 16.6 in November, while for CIV copepodites it increases to 12.9 (Tande 1982). For Metridia longa females, it increases from < 6.0 in July to 10.0 in November (Grønvik \& Hopkins 1984). The most lipid-rich copepod species in our study area, Calanoides acutus, is analogous to $C$. finmarchicus; it overwinters at depths below $250 \mathrm{~m}$ (Lopez et al. 1993), well below the 50 to $150 \mathrm{~m}$ stratum in which $E$. superba in this region is found in winter (Zhou et al. in press), and thus it is not likely to be an accessible prey item. Abundant copepod species in near-surface waters, such as Oncaea spp., Oithona spp. and Metridia spp. (Hopkins et al. 1993), might have somewhat higher body $\mathrm{C}: \mathrm{N}$ ratios in winter than in summer. It is difficult to fix a precise value for the $C: N$ ratio of $E$. superba's crustacean prey in winter. By specifying a winter C: $\mathrm{N}$ ratio of $9.0 \pm 2.0$ we allow that the range may be considerable, and that it is higher than the summer mean of 8.0 (Båmstedt 1986).

The $C: N$ ratio of egested matter can also be expressed as a function of ingestion rate and the assimilation efficiencies of carbon $\left(a_{C}\right)$ and nitrogen $\left(a_{N}\right)$; 


$$
\frac{E_{C}}{E_{N}}=\frac{I_{C}}{I_{N}} \times \frac{1-a_{C}}{1-a_{N}}
$$

Substituting $a_{C}=0.70$ (cf. Conover 1978, Clarke et al. 1988) and solving for the assimilation efficiency of nitrogen, we obtain

$$
a_{\mathrm{N}}=\frac{I_{\mathrm{C}}}{I_{\mathrm{N}}}\left(\frac{I_{\mathrm{N}}}{I_{\mathrm{C}}}-\frac{E_{\mathrm{N}}}{E_{\mathrm{C}}}+a_{\mathrm{C}} \frac{E_{\mathrm{N}}}{E_{\mathrm{C}}}\right)=0.85
$$

Combining Eqs. (1) \& (2), we may also express the ratio of growth rates in terms of carbon and nitrogen as

$$
\frac{G_{C}}{G_{N}}=\frac{a_{C} I_{C}-R}{a_{N} I_{N}-X}
$$

The ratio of carbon respired to nitrogen excreted (by weight), $R / X$, is related to the atomic $\mathrm{O}: \mathrm{N}$ ratio by

$$
\frac{R}{X}=0.428(O: N)
$$

Now, by substituting $R=X(R / X)$ and $I_{\mathrm{C}}=I_{\mathrm{N}}\left(I_{\mathrm{C}} / I_{\mathrm{N}}\right)$ into $\mathrm{Eq} .(16)$, and solving for $O: N$, we obtain

$$
O: N=2.34\left[\frac{G_{\mathrm{C}}}{G_{\mathrm{N}}}-\frac{I_{\mathrm{N}}}{X}\left(a_{\mathrm{N}} \frac{G_{\mathrm{C}}}{G_{\mathrm{N}}}-a_{\mathrm{C}} \frac{I_{\mathrm{C}}}{I_{\mathrm{N}}}\right)\right]
$$

The only variable in this equation for which we have no value is $I_{N} / X$, the ratio of nitrogen ingested to nitrogen excreted. However, this is related to the net growth efficiency with respect to nitrogen, $K_{2(\mathrm{~N})}$, by

$$
\frac{I_{N}}{X}=\frac{1}{a_{N}\left(1-K_{2(N)}\right)}
$$

Substituting Eq. (19) into Eq. (18), we can now express the $O: N$ ratio as

$$
O: N=2.34\left[\frac{G_{C}}{G_{N}}-\frac{1}{1-K_{2(N)}}\left(\frac{G_{C}}{G_{N}}-\frac{a_{C}}{a_{N}} \times \frac{I_{C}}{I_{N}}\right)\right]
$$

in which we have values for all variables except for $K_{2(\mathrm{~N})}$. In the case where ingestion is positive, but where

\begin{tabular}{|c|c|c|c|}
\hline$I_{\mathrm{C}} / I_{\mathrm{N}}$ & $a_{N}$ & $\frac{K_{1(\mathrm{C})}=0.092}{K_{2(\mathrm{~N})}}$ & $\frac{K_{1(C)}=0.17}{K_{2(\mathrm{~N})}}$ \\
\hline 5 & 0.89 & 0.108 & 0.200 \\
\hline 6 & 0.87 & 0.133 & 0.245 \\
\hline 7 & 0.85 & 0.159 & 0.293 \\
\hline 8 & 0.83 & 0.186 & 0.344 \\
\hline 9 & 0.81 & 0.215 & 0.397 \\
\hline
\end{tabular}

Table 5. Euphausia superba. Net growth efficiency with respect to nitrogen $\left(K_{2(N)}\right)$ as a function of the C:N ratio of prey $\left(I_{C} / I_{N}\right)$, the assimilation efficiency of nitrogen $\left(a_{N}\right)$ and 2 values at the extremes of Ikeda's (1984) estimates of the gross growth efficiency in terms of carbon $\left(K_{1(C)}\right)$ for the summer growth period in E. superba. See Eq. (22) in text. growth is equal to zero, the $\mathrm{O}: \mathrm{N}$ ratio simplifies to

$$
(O: N)_{(G=0)}=2.34\left(\frac{a_{C}}{a_{N}} \times \frac{I_{C}}{I_{N}}\right)
$$

For cases where growth is positive we require a value for the net growth efficiency of nitrogen. The gross growth efficiency of Euphausia superba with respect to carbon $\left(K_{1(\mathrm{C})}\right)$ was estimated by Ikeda (1984) for summer growing periods of 120 to $180 \mathrm{~d}$, following several different growth schemes. The range of his values was 0.092 to 0.17 . This allows us to place upper bounds on the net growth efficiency of $E$ superba in terms of nitrogen, which is related to $K_{1(\mathrm{C})}$ by

$$
K_{2(\mathrm{~N})}=\frac{K_{1(\mathrm{C})}}{a_{N}} \times \frac{G_{\mathrm{N}}}{G_{\mathrm{C}}} \times \frac{I_{\mathrm{C}}}{I_{\mathrm{N}}}
$$

Evaluation of Eq. (22) for Ikeda's (1984) values of $K_{1(\mathrm{C})}$ suggests that the upper limit for $K_{2(\mathrm{~N})}$ would be in the range 0.108 to 0.397 , depending on the $C: N$ ratio of its prey (Table 5).

Euphausia superba's $\mathrm{O}: \mathrm{N}$ ratio varies as a function of both the C:N ratio of its prey, $I_{C} / I_{N}$, and its net growth efficiency in terms of nitrogen, $K_{2(\mathrm{~N})}$ (Fig. 12). If krill ingestion rate were zero throughout the winter, then, in order to maintain its body $\mathrm{C}: \mathrm{N}$ ratio of 4.76 , its $\mathrm{O}: \mathrm{N}$ ratio would have to be $O: N=2.34\left(G_{C} / G_{N}\right)=11.14$. This value is sufficiently low to suggest respiratory combustion of almost pure protein, which would be indicated by an O:N ratio of around 8 (Mayzaud \& Conover 1988). Such a condition would also be consistent with starvation metabolism (Ikeda \& Dixon 1982)

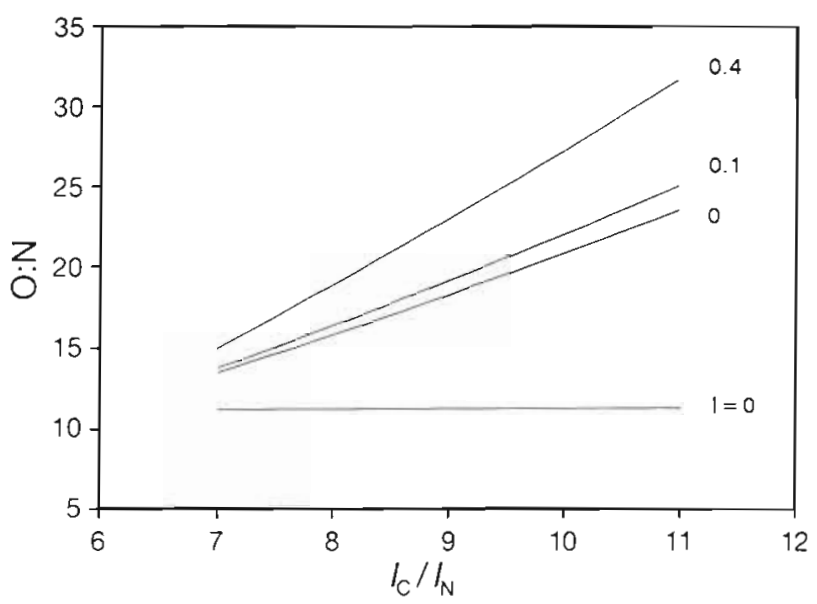

Fig. 12. Euphausia superba. Atomic $O: N$ ratio predicted by the model developed in this paper, as a function of the body C:N ratio of prey and the net growth efficiency with respect to nitrogen $\left(K_{2(N)}\right)$. The relation is shown for net growth efficiencies of 0 (no growth), 0.1 and 0.4 , the latter 2 values corresponding to Ikeda's (1984) estimates of growth efficiency during summer. Also shown is the $\mathrm{O}: \mathrm{N}$ ratio predicted for an ingestion rate of zero $(I=0)$. See Eqs. (20) \& (21) in text 
However, our observations show that E. superba was actively feeding. For krill with a positive growth rate feeding on prey with a $C: N$ ratio of 8.0 , the predicted $\mathrm{O}: \mathrm{N}$ ratio would be in the range 15.7 to 18.8 . These values can be compared to measurements made on E. superba in summer. Suspended particulate matter in coastal waters of the Antarctic Peninsula during summer has a $\mathrm{C}: \mathrm{N}$ ratio in the range 7.3 to 8.2 (Karl et al. $1991 \mathrm{~b})$, and summer measurements of krill $\mathrm{O}: \mathrm{N}$ ratio are in the range 15.9 to 17.5 (Ikeda \& Mitchell 1982). This close agreement between prediction and observation suggests that our model may be quite accurate.

We are now in a position to predict parameter values for a complete physiological budget in terms of both carbon and nitrogen. The excretion rate of nitrogen, $X\left(\mu \mathrm{g} \mathrm{h}^{-1}\right)$, can be predicted from the empirically determined relation (Table 1 )

$$
X=0.346 N_{1}^{0.739}
$$

where $N_{t}=$ nitrogen body weight ( $\mathrm{mg} \mathrm{N}$ ) at time $t$, and converted to units of $\mathrm{mg} \mathrm{d}^{-1}$. By rearranging Eq. (18) the ingestion rate of nitrogen, $I_{N}$, can be determined from the excretion rate and the ratios previously mentioned:

$$
I_{\mathrm{N}}=\frac{X\left[\frac{G_{C}}{G_{N}}-0.428(O: N)\right]}{a_{N} \frac{G_{C}}{G_{N}}-a_{C} \frac{I_{C}}{I_{N}}}
$$

Respiration was determined by a rearrangement of Eq. (17), i.e.

$$
R=0.428(O: N)
$$

and the ingestion rate of carbon, $I_{C}$, by rearranging Eq. (24):

$$
I_{C}=\frac{\frac{G_{C}}{G_{N}} \times X[1-0.428(O: N)]}{a_{N} \frac{G_{C}}{G_{N}} \times \frac{I_{N}}{I_{C}}-a_{C}}
$$

Daily rates of excretion, ingestion and respiration were used to calculate daily growth rates from Eqs. (1) \& (2). The resulting daily changes in body weight of carbon and nitrogen were then used to estimate concomitant changes in dry weight and body length, as for the first 2 model scenarios.

Losses of carbon and nitrogen due to molting were gauged to be insignificant. Assuming that Euphausia superba molt approximately once per month (Buchholz 1991), that the weight of each molt represents $5 \%$ of body weight (Lasker 1966), and that the molted exoskeleton contains a low percentage of both carbon $(23.8 \%)$ and nitrogen $(4.4 \%)$ by comparison to the whole animal (Ikeda 1984), then the daily loss due to molting would represent only 4 to $9 \%$ of total metabolic losses - a negligible amount.

\section{Model output and comparison to observations}

We ran the model for 2 cases. In the first case we assumed that ingestion in winter was sufficient only to meet metabolic needs (i.e. $G=0$ ). In the second case we assumed that ingestion was sufficient for growth at a net growth efficiency of $K_{2(\mathrm{~N})}=0.25$, the mean of Ikeda's (1984) estimates for summer growth. In both cases we asked whether the resulting estimates of daily ration $\left(I_{C} / C\right.$ or $\left.I_{N} / N\right)$ could reasonably be met by the ingestion of copepod prey, and we compared our estimates of respiration to independent published values.

The rate of ingestion that Euphausia superba requires to meet its metabolic needs throughout the winter is modest. In terms of carbon, metabolic demands would require a ration of 0.80 to $2.76 \% \mathrm{~d}^{-1}$, depending on body size and the $\mathrm{C}: \mathrm{N}$ ratio of its prey; in terms of nitrogen the value is slightly smaller, in the range of 0.54 to $1.19 \%$ body $\mathrm{N} \mathrm{d}^{-1}$ (Table 6$)$. If this ration had to be obtained in the form of Metridia gerlachei females with a body weight of $81 \mu \mathrm{g} \mathrm{C}$ (Price et al. 1988), then a $20 \mathrm{~mm}$ krill would need to eat approximately 1 copepod every day, a $30 \mathrm{~mm}$ krill 2.5 copepods $\mathrm{d}^{-1}$, and a $40 \mathrm{~mm}$ krill from 4.3 to 7.5 copepods $\mathrm{d}^{-1}$. In order to grow during the winter with a net growth efficiency of $K_{2(\mathbb{N})}=0.25, E$. superba's ingestion rate of $M$. gerlachei would not even need to double. A $20 \mathrm{~mm}$ krill would require less than 1.5 copepods $\mathrm{d}^{-1}$, a $30 \mathrm{~mm}$ krill approximately 3.5 copepods $\mathrm{d}^{-1}$, and a $40 \mathrm{~mm}$ krill from 5.7 to 10.0 copepods $\mathrm{d}^{-1}$ (Table 6).

There is every indication that Euphausia superba is capable of such carnivorous ingestion in nature. Hopkins \& Torres (1989) found that $>20 \%$ of the krill guts they examined contained Metridia gerlachei or other copepods $_{i}>50 \%$ contained coelenterate fragments. Similar findings have been reported elsewhere in winter (Lancraft et al. 1991). Price et al. (1988) found that krill of approximately $100 \mathrm{mg}$ body C, slightly more than twice the weight of the largest krill in our model, ingested as many as $3 \mathrm{M}$. gerlachei $\mathrm{h}^{-1}$, equivalent to 70 copepods $\mathrm{d}^{-1}$. Our own observations of predation on Oncaea and Oithona spp. (Table 3), which have body weights of $\mathrm{ca} 1 \mu \mathrm{g} \mathrm{C}$, indicate the potential to surpass the carbon requirements for significant growth (Table 6). These are the results of laboratory experiments, which can be criticized for a variety of reasons. However, the important fact they demonstrate is that E. superba is well capable of ingesting copepods at 

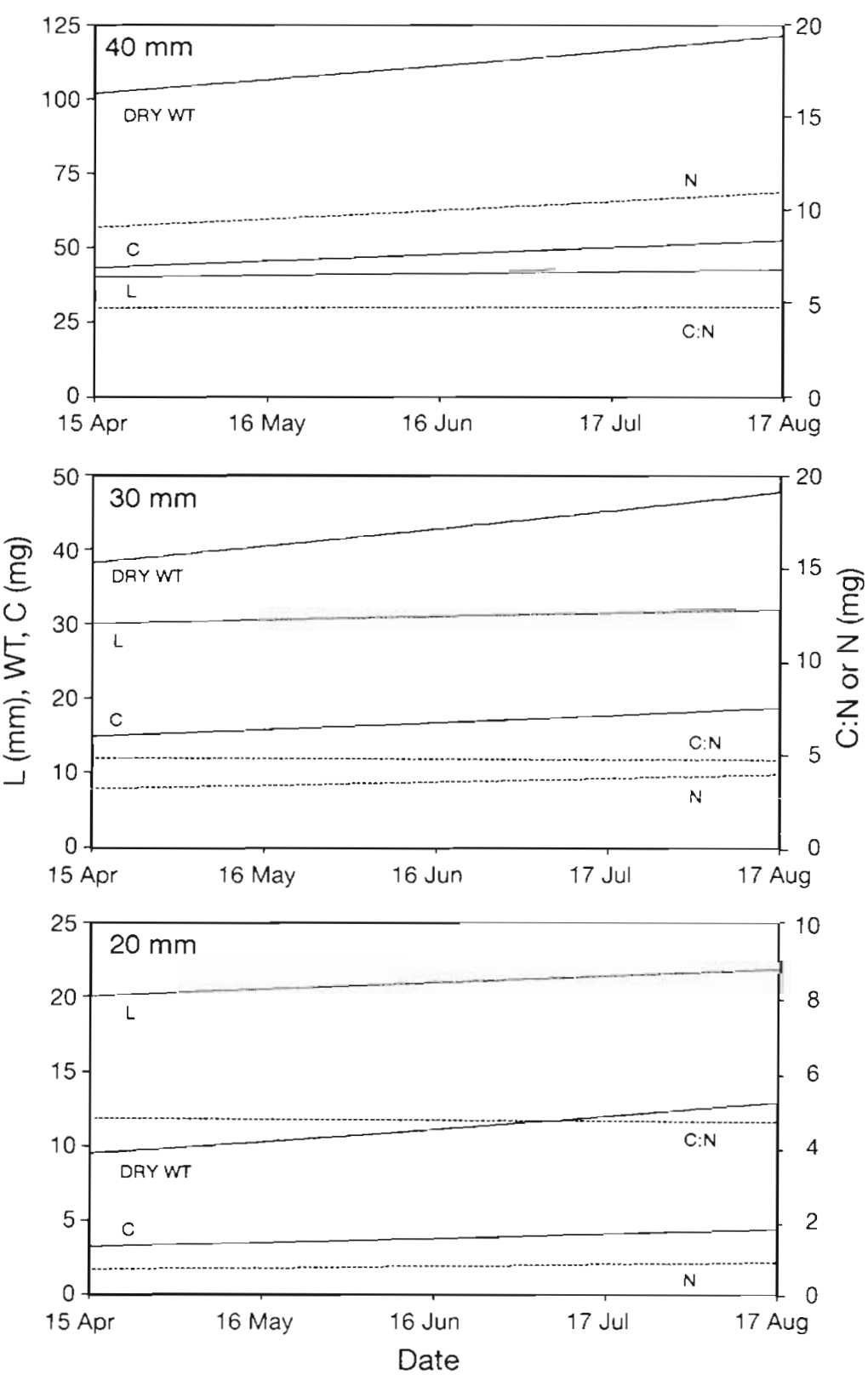

Fig. 13. Euphausia superba. Model predictions as in Figs. $10 \& 11$, based on the model developed in this paper. Model assumes a constant body $\mathrm{C}: \mathrm{N}$ ratio during winter (as observed), and excretion rates based on measurements shown in Fig. 6. Results shown here assume a net growth efficiency of

$$
K_{2(\mathrm{~N})}=0.25
$$

values (Fig. 14). Allowing for a range of 7.0 to 11.0 in the prey $\mathrm{C}: \mathrm{N}$ ratio at a net growth efficiency of 0.25 , with respect to nitrogen, predicted respiration rates approach those reported in the literature; Ikeda's (1984) values are similar to others (Ikeda \& Mitchell 1982, Segawa et al. 1982, Rakusa-Suszczewski 1990). Changes in the assumed $\mathrm{C}: \mathrm{N}$ ratio of prey have a greater effect on predicted respiration than changes in the growth efficiency. Assuming the reported respiration values to be correct, it appears that $\mathrm{C}: \mathrm{N}$ ratio of prey might be closer to 11.0 than to 9.0 .

Another means of assessing our model output is to compare its predictions for the increase in body length during winter to observed changes in the size structure of field populations. During the 4 mo period from April to August, at a growth rate consistent with $K_{2(\mathbb{N})}=0.25$, krill with initial sizes in the range 20 to $40 \mathrm{~mm}$ would be expected to increase in length by ca $2 \mathrm{~mm}$ (Fig. 13). This prediction compares well with several field obser. vations. The dominant mode of the Euphausia superba population in Gerlache Strait in January 1992 was approximately $20 \mathrm{~mm}$ (Fig. 15). The great similarity in the size structure of the population at the same location in July 1992 indicates that it could well have been the same population observed 6 mo earlier. The increase in body length of almost $3.0 \mathrm{~mm}$ in all size classes suggests a growth efficiency of $K_{2(\mathrm{~N})} \cong 0.3$. Similar increases in length during winter shown by reanalysis of Marr's (1962) data (Rakusa-Suszczewski 1990), as well as in a population observed through an entire seasonal cycle in Admiralty Bay (Stepnik 1982), suggest equally high growth efficiencies during winter. much greater rates than would be required for growth. That krill are able to do so in July and August suggests that they are not physiologically committed to an overwintering strategy that requires a reduction in feeding.

Model predictions of the changes in body length, carbon, nitrogen and dry weight for krill growing through the winter with a growth efficiency of $K_{2(\mathrm{~N})}=0.25$ are shown in Fig. 13. Corresponding rates of respiration from the model compare favorably with published

\section{Overwintering strategy of Euphausia superba}

The field observations and results of the physiological model presented here suggest a seasonal pattern in the feeding behavior of Euphausia superba that allows for year-round growth. In spring and summer krill are predominantly herbivorous, though even then occasional animal food may be ingested (Hopkins 1985). The greatest concentrations of phyto- 


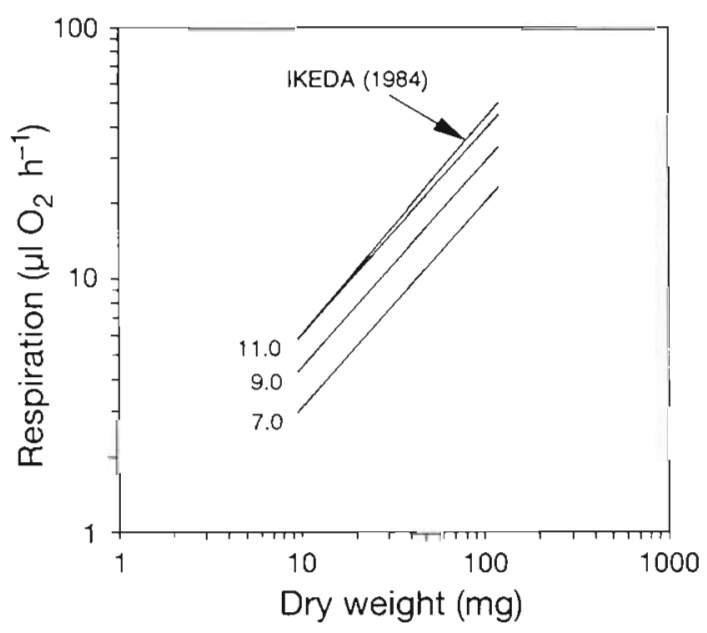

Fig. 14. Euphausia superba. Winter respiration rate as a function of body dry weight predicted by the physiological model for prey $C: N$ ratios of $7.0,9.0$ and 11.0 , compared to relationships reported for respiration of krill in summer by lkeda (1984)

plankton and zooplankton are generally found in coastal regions in spring and summer, so it is not surprising that $E$. superba, being nektonic, also aggregate there in greatest abundance (Marr 1962). As the period of high primary production draws to a close in autumn and phytoplankton food becomes scarce, the

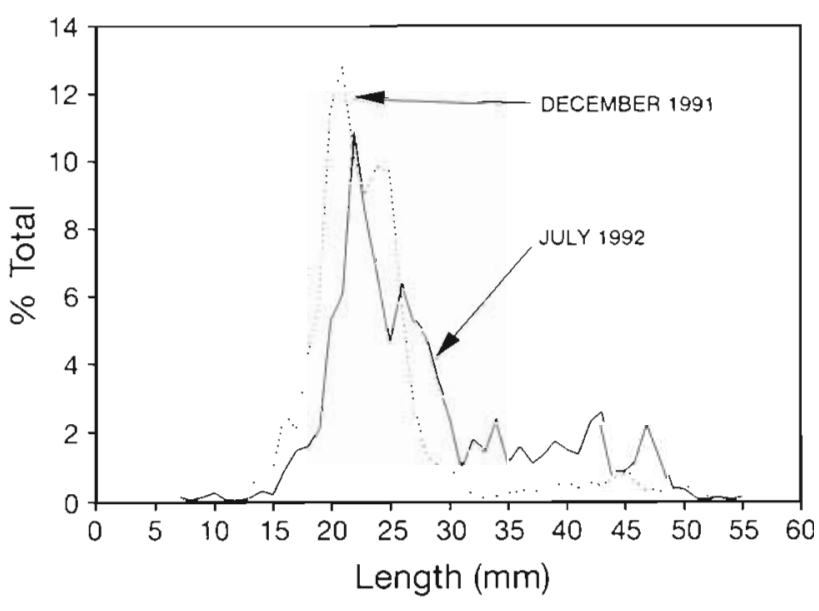

Fig. 15. Euphausia superba. Size-frequency structure of the population in Gerlache Strait in summer (Dec-Jan) and winter (Jul-Aug) 1992. Data are the mean of samples collected from 18 stations during a $3 \mathrm{wk}$ period in summer and 35 stations during a $3 \mathrm{wk}$ period in winter

krill diet becomes predominantly carnivorous. During winter krill remain in the upper $200 \mathrm{~m}$ of the water column (Zhou et al. in press), approximately where they were in summer, and feed on the relatively high abundances of zooplankton remaining from the productive summer. This mode of feeding continues until

Table 6. Euphausia superba. Model predictions of daily rations of carbon and nitrogen (\% $\mathrm{d}^{-1}$ ) for individuals of 20,30 and $40 \mathrm{~mm}$ in length, as a function of body $\mathrm{C}: \mathrm{N}$ ratio for zero growth $\left(K_{2(\mathrm{~N})}=0\right)$ and growth at $K_{2(\mathrm{~N})}=0.25$. The daily carbon requirement $\left(\mu \mathrm{C} \mathrm{C} \mathrm{d}^{-1}\right)$ is also expressed as the number of Metridia gerlachei females required ( $\mathrm{Mg}$ equiv.) per day

\begin{tabular}{|c|c|c|c|c|c|c|c|c|}
\hline $\begin{array}{l}\text { Length } \\
(\mathrm{mm})\end{array}$ & $\begin{array}{c}\text { Body C } \\
\text { (mg) }\end{array}$ & $\begin{array}{c}\text { Body N } \\
\text { (mg) }\end{array}$ & $I_{\mathrm{C}} / I_{\mathrm{N}}$ & $O: N$ & $\begin{array}{l}\mathrm{Dc} \\
\mathrm{C}\end{array}$ & on $\% \mathrm{~N}$ & $\begin{array}{l}\text { Ingestion } \\
\left(\mu \mathrm{g} \mathrm{C} d^{-1}\right)\end{array}$ & $\begin{array}{l}\text { Mg equiv } \\
\left(\text { no. }^{-1}\right)\end{array}$ \\
\hline \multicolumn{9}{|l|}{$K_{2(\mathrm{~N})}=0$} \\
\hline 20 & 3.25 & 0.7 & $\begin{array}{r}7 \\
9 \\
11\end{array}$ & $\begin{array}{l}13.42 \\
18.16 \\
23.42\end{array}$ & $\begin{array}{l}1.57 \\
2.14 \\
2.76\end{array}$ & $\begin{array}{l}1.07 \\
1.13 \\
1.19\end{array}$ & $\begin{array}{l}51.0 \\
69.6 \\
89.7\end{array}$ & $\begin{array}{l}0.6 \\
0.9 \\
1.1\end{array}$ \\
\hline 30 & 14.8 & 3.1 & $\begin{array}{r}7 \\
9 \\
11\end{array}$ & $\begin{array}{l}13.42 \\
18.16 \\
23.42\end{array}$ & $\begin{array}{l}1.06 \\
1.44 \\
1.86\end{array}$ & $\begin{array}{l}0.72 \\
0.76 \\
0.80\end{array}$ & $\begin{array}{l}156.9 \\
213.1 \\
275.3\end{array}$ & $\begin{array}{l}1.9 \\
2.6 \\
3.4\end{array}$ \\
\hline 40 & 43.2 & 9.2 & $\begin{array}{r}7 \\
9 \\
11\end{array}$ & $\begin{array}{l}13.42 \\
18.16 \\
23.42\end{array}$ & $\begin{array}{l}0.80 \\
1.09 \\
1.40\end{array}$ & $\begin{array}{l}0.54 \\
0.58 \\
0.61\end{array}$ & $\begin{array}{l}345.6 \\
470.9 \\
604.8\end{array}$ & $\begin{array}{l}4.3 \\
5.8 \\
7.5\end{array}$ \\
\hline \multicolumn{9}{|c|}{$K_{2(\mathbb{N})}=0.25$} \\
\hline 20 & 3.25 & 0.7 & $\begin{array}{r}7 \\
9 \\
11\end{array}$ & $\begin{array}{l}14.19 \\
20.51 \\
27.52\end{array}$ & $\begin{array}{l}2.09 \\
2.84 \\
3.67\end{array}$ & $\begin{array}{l}1.42 \\
1.50 \\
1.59\end{array}$ & $\begin{array}{r}68.0 \\
92.3 \\
119.3\end{array}$ & $\begin{array}{l}0.8 \\
1.1 \\
1.5\end{array}$ \\
\hline 30 & 14.8 & 3.1 & $\begin{array}{r}7 \\
9 \\
11\end{array}$ & $\begin{array}{l}14.19 \\
20.51 \\
27.52\end{array}$ & $\begin{array}{l}1.41 \\
1.91 \\
2.47\end{array}$ & $\begin{array}{l}0.96 \\
1.01 \\
1.07\end{array}$ & $\begin{array}{l}208.7 \\
282.7 \\
365.6\end{array}$ & $\begin{array}{l}2.6 \\
3.5 \\
4.5\end{array}$ \\
\hline 40 & 43.2 & 9.2 & $\begin{array}{r}7 \\
9 \\
11\end{array}$ & $\begin{array}{l}14.19 \\
20.51 \\
27.52\end{array}$ & $\begin{array}{l}1.07 \\
1.45 \\
1.87\end{array}$ & $\begin{array}{l}0.73 \\
0.77 \\
0.81\end{array}$ & $\begin{array}{l}460.9 \\
626.4 \\
807.8\end{array}$ & $\begin{array}{r}5.7 \\
7.7 \\
10.0\end{array}$ \\
\hline
\end{tabular}


late winter, when daylength increases and primary production in the sea ice (Kottmeier \& Sullivan 1987) gives rise to high abundances of microalgae (Daly 1990). As the season progresses, krill move toward regions such as the marginal ice zone where the foodladen sea ice has begun to disintegrate, first scraping algae from the ice, and then taking advantage of the tremendous concentrations that form when the sea ice finally melts (Marschall 1988). With populations following the retreat of the sea ice to coastal regions in spring, the seasonal cycle is complete. Growth continues throughout the year.

This scenario is consistent with numerous observations on the feeding behavior and distribution of Euphausia superba. There is no need to invoke unusual physiological mechanisms such as starvation or reduced metabolism in order to explain how krill survive the winter. Krill may shrink when subjected to long periods of starvation (Ikeda \& Dixon 1982, Nicol et al. 1992), but this does not mean that they do so in nature. If shrinkage does occur in field populations, we suggest that such populations are not representative of this nektonic species, which is capable of swimming great distances in order to find food. All available evidence suggests that, in regions where krill are abundant, a $20 \mathrm{~mm}$ individual should experience little difficulty in finding and eating the equivalent of 1 Metridia gerlachei female every other day - all that it requires to meet its metabolic needs.

We cannot explain the disparity between our conclusions and those of Quetin \& Ross (1991), who concluded that krill west of the Antarctic Peninsula must starve, and probably shrink, in winter. It is possible that in the years of their investigations there were fewer zooplankton than we observed in 1992, but this seems unlikely. We find no evidence for low rates of fecal production in winter, nor for the 'reduced' rates of respiration they reported. On the contrary, we suggest that the normal behavior of Euphausia superba in coastal waters of the Antarctic Peninsula, and probably throughout those regions where it is most abundant, involves carnivorous feeding and continued growth at relatively high efficiency throughout the winter.

Acknowledgements. We thank V. Øresland for shaning his observations on gut contents of freshly caught E. superba; P. J. Perl, S. Beaulieu and A. Gonzalez for their assistance in measurements of ammonium and phosphate excretion; $E$. Brinton for data on $E$. superba population size structure in Gerlache Strait in summer; and the officers and crew of the RVIB 'Nathaniel B. Palmer' for their willingness to take us to relatively inaccessible locations. We also thank $\mathrm{V}$. Øresland and 3 anonymous reviewers for suggestions which improved the manuscript. The logistic support of Antarctic Support Associates, coordinated by Skip Owen, was invaluable. This research was part of the RACER (Research on Antarctic Coastal Ecosystem Rates) program supported by grant no. DPP-88-17779 from the Office of Polar Programs, U.S. National Science Foundation, to M.H.

\section{LITERATURE CITED}

Båmstedt, U. (1986). Chemical composition and energy content. In: Corner, E. D. S., O'Hara, S. C. M. (eds.) The biological chemistry of marine copepods. Clarendon Press, Oxford, p. 1-58

Bargmann, H. E. (1945). The development and life-history of adolescent and adult krill Euphausia superba. 'Discovery' Rep. 23: 103-176

Brinton, E. (1991). Distribution and population structures of immature and adult Euphausia superba in the western Bransfield Strait region during the $1986-87$ summer. Deep Sea Res. 38: 1169-1193

Buchholz, F. (1991). Moult cycle and growth of Antarctic krill Euphausia superba in the laboratory. Mar. Ecol. Prog. Ser. 69: $217-229$

Butler, E. I., Corner, E. D. S., Marshall, S. M. (1970). On the nutrition and metabolism of zooplankton. VII. Seasonal survey of nitrogen and phosphorous excretion by Calanus in the Clyde Sea area. J. mar. biol. Ass. U.K. 50: 525-560

Chekunova, V. I., Rynkova, T. I. (1974). Energy requirements of the Antarctic crustacean Euphausia superba Dana. Oceanology 14: $434-440$

Clarke, A. (1980). The biochemical composition of krill, Euphausia superba Dana, from South Georgia. J. exp. mar. Biol. Ecol. 43: 221-236

Clarke, A., Quetin, L. B., Ross, R. M. (1988). Laboratory and field estimates of the rate of fecal pellet production by Antarctic krill, Euphausia superba. Mar. Biol. 98: $557-563$

Conover, R. J. (1978). Transformation of organic matter. In: Kinne, O. (ed.) Marine ecology, Vol. 4. Wiley-Interscience, Chichester, p. 221-499

Corner, E. D. S., Davies, A. G. (1971). Plankton as a factor in the nitrogen and phosphorous cycles in the sea. Adv. mar. Biol. 48: 49-75

Comer, E. D. S., Head, R. N., Kilvington, C. C., Pennyquick, L. (1976). On the nutrition and metabolism of zooplankton. $X$. Quantitative aspects of Calanus helgolandicus feeding as a carnivore. J. mar. biol. Ass. U.K. 52: 847-861

Daly, K. L. (1990). Overwintering development, growth, and feeding of larval Euphausia superba in the Antarctic marginal ice zone. Limnol. Oceanogr. 35: 1564-1576

Falk-Petersen, S. (1985). Growth of the euphausiids Thysanoessa inermis, Thysanoessa raschii, and Meganyctiphanes norvegica in a subarctic fjord, North Norway. Can. J. Fish. Aquat. Sci. 42: 14-22

Ferguson, C. F., Raymont, J. K. B. (1974). Biochemical studies on marine zooplankton. XII. Further investigations on Euphausia superba Dana. J. mar. biol. Ass. U.K. 54: 719-725

Gnaiger, E. (1983). Calculation of energetic and biochemical equivalents of respiratory oxygen consumption. In: Gnaiger, E., Forstner, H. (eds.) Polarographic oxygen sensors. Springer-Verlag, Berlin, p. 337-345

Grønvik, S., Hopkins, C. C. E. (1984). Ecological investigations on the zooplankton community of Balsfjorden, northern Norway: generation cycle, seasonal vertical distribution, and seasonal variations in body weight and carbon and nitrogen content of the copepod Metridia longa (Lubbock). J. exp. mar. Biol. Ecol. 80: 93-107 
Holm-Hansen, O., Mitchell, B. G. (1991). Spatial and temporal distribution of phytoplankton and primary production in the western Bransfield Strait region. Deep Sea Res. 38: 961-980

Holm-Hansen, O., Mitchell, B. G., Hewes, C. D., Karl, D. M. (1989). Phytoplankton blooms in the vicinity of Palmer Station, Antarctica. Polar Biol. 10: 49-57

Hopkins, T L. (1985). Food web of an Antarctic midwater ecosystem. Mar. Biol. 89: 197-212

Hopkins, T. L., Lancraft, T. M., Torres, J. J., Donnelly, J. (1993). Community structure and trophic ecology of zooplankton in the Scotia Sea marginal ice zone in winter (1988). Deep Sea Res. 40: 81-105

Hopkins, T. L., Torres, J. J. (1989). Midwater food web in the vicinity of a marginal ice zone in the western Weddell Sea. Deep Sea Res. 36: 543-560

Ikeda, T. (1974). Nutritional ecology of marine zooplankton. Mem. Fac. Fish. Hokkaido Univ. 22: 1-97

Ikeda, T. (1981). Metabolic activity of larval stages of Antarctic krill. Antarct. J. U.S. 16: 161-162

Ikeda, $T$ (1984). Sequences in metabolic rates and elemental composition (C, N, P) during the development of Euphausia superba Dana and estimated food requirements during its life span. J. Crust. Biol. 4: 273-284

Ikeda, T., Bruce, B. (1986). Metabolic activity and elemental composition of krill and other zooplankton from Prydz Bay, Antarctica, during early summer (NovemberDecember). Mar. Biol. 92: 545-555

Ikeda, T., Dixon, P. (1982). Body shrinkage as a possible overwintering mechanism of the Antarctic krill, Euphausia superba Dana. J. exp. mar. Biol. Ecol. 62: 143-151

Ikeda, T., Kirkwood, R. (1989). Metabolism and body composition of two euphausiids (Euphausia superba and E. Crystallorophias) collected from under pack-ice off Enderby Land, Antarctica. Mar. Biol. 100: 301-308

Ikeda, T., Mitchell, A. W. (1982). Oxygen uptake, ammonia excretion and phosphate excretion in krill and other Antarctic zooplankton in relation to their body size and chemical composition. Mar. Biol. 71: 283-298

Karl, D. M., Holm-Hansen, O., Taylor, G. T., Tien, G., Bird, D. F. (1991a). Microbial biomass and productivity in the western Bransfield Strait, Antarctica during the 1986-87 austral summer. Deep Sea Res. 38: 1029-1056

Karl, D. M., Tilbrook, B., Tien, G. (1991b). Seasonal coupling of organic matter production and particle flux in the western Bransfield Strait, Antarctica. Deep Sea Res. 38: $1097-1126$

Kato, M., Segawa, S., Tanoue, E., Murano, M. (1982). Filtering and ingestion rates of the Antarctic krill Euphausia superba Dana. Trans. Tokyo Univ. Fish. 5: 167-175

Kawaguchi, K., Ishikawa, S., Matsuda, O. (1986). The overwintering strategy of Antarctic krill (Euphausia superba Dana) under the coastal fast ice of the Ongul Islands in Lützow-Holm Bay, Antarctica. Mem. Inst. Polar Res. Japan 44: $67-85$

Kottmeier, S., Sullivan, C. W. (1987). Late winter primary and bacterial production in sea ice and seawater west of the Antarctic Peninsula. Mar. Ecol. Prog. Ser. 36: 287-298

Lancraft, T. M., Hopkins, T. L., Torres, J. J., Donnelly, E. (1991). Oceanic micronektonic/macrozooplanktonic community structure and feeding in ice covered Antarctic waters during the winter (AMERIEZ 1988). Polar Biol. 11: $157-167$

Lasker, R. (1966). Feeding, growth, respiration and carbon utilization of a euphausiid crustacean. J. Fish. Res. Bd Can. 23: 1291-1317

Le Borgne, R. (1986). The release of soluble end products of metabolism. In: Corner, E. D. S., O'Hara, S. C. M. (eds.) The biological chemistry of marine copepods. Clarendon Press, Oxford, p. 109-164

Lopez, M. D. G., Huntley, M. E., Lovette, J. T (1993). Calanoides acutus in Gerlache Strait, Antarctica. I. Distribution of late copepodite stages and reproduction during spring. Mar. Ecol. Prog. Ser. 100: 153-165

Lovegrove, T. (1962). The effect of various factors on dry weight values. Rapp. P.-v. Cons. perm. int. Explor. Mer 153: $86-91$

Marr, J. W. S. (1962). The natural history and geography of the Antarctic krill (Euphausia superba Dana). 'Discovery' Rep. 322: 33-464

Marschall, H.-P. (1988). The overwintering strategy of Antarctic krill under the pack-ice of the Weddell Sea. Polar Biol. 9: $129-135$

Mayzaud, P., Conover, R. J. (1988). O:N atomic ratio as a tool to describe zooplankton metabolism. Mar. Ecol. Prog. Ser. 45: $289-302$

McClatchie, S. (1988). Food-limited growth of Euphausia superba in Admiralty Bay, South Shetland Islands, Antarctica. Cont. Shelf Res. 8: 329-345

McClatchie, S., Rakusa-Suszczewski, S., Fileck, K. (1991). Seasonal growth and mortality of Euphausia superba in Admiralty Bay, South Shetland Islands, Antarctica. ICES J. mar. Sci. 48: 335-342

Morris, D., Priddle, J. (1984). Observations on the feeding and moulting of the Antarctic krill, Euphausia superba Dana, in winter. Br. Antarct. Surv. Bull. 65: 57-63

Morris, D. J., Watkins, J. L., Ricketts, C., Buchholz, F., Priddle, J. (1988). An assessment of the merits of length and weight measurements of Antarctic krill Euphausia superba. Br. Antarct. Surv. Bull. 79: 27-50

Nicol, S., Stolp, M., Cochran, T., Geijsel, P., Marshall, J. (1992). Growth and shrinkage of Antarctic krill Euphausia superba from the Indian Ocean sector of the Southern Ocean during summer. Mar. Ecol. Prog. Ser. 89: 175-181

Nordhausen, W., Huntley, M. E. (1990). RACER: carbon egestion rates of Euphausia superba. Antarct. J. U.S. 25: 161-162

Nöthig, E. M., Bathmann, U., Jennings, J., Fahrbach, E. Gradinger, R., Gordon, L., Makarov, R. (1992). Regional relationships between biological and hydrographical properties in the Weddell Gyre in late austral winter 1989. J. mar. Chem. 35: 325-336

Omori, M. (1969). Weight and chemical composition of some important oceanic zooplankton in the North Pacific Ocean. Mar. Biol. 3: 4-10

Omori, M., Ikeda, T. (1984). Methods in marine zooplankton ecology. John Wiley \& Sons, New York

Pavlov, V. Y. (1969). The feeding of krill and some features of its behaviour. Trudy VNIRO 66: 207-222 (MAFF Translation NS No. 94)

Price, H. J., Boyd, K. R., Boyd, C. M. (1988). Omnivorous feeding behavior of the Antarctic krill Euphausia superba. Mar. Biol. 97: 67-77

Quetin, L. B., Ross, R. M. (1991). Behavioral and physiological characteristics of the Antarctic krill, Euphausia superba. Am. Zool. 31: 49-63

Rakusa-Suszczewski, S. (1990). Seasonal changes in respiration and biomass of Euphausia superba Dana from Admiralty Bay (South Shetland Islands, Antarctica). Pol. Arch. Hydrobiol. 37: 305-311

Raymont, J. E. G., Srinivasagam, R. T., Raymont, J. K. B (1971). Biochemical studies on marine zooplankton. IX. The biochemical composition of Euphausia superba. J. mar. biol. Ass. U.K. 51: 581-588 
Reeve, M. R. (1981). Large cod-end reservoirs as an aid to the live collection of zooplankton. Limnol. Oceanogr. 26: $577-579$

Segawa, S., Kato, M., Muruno, M. (1982). Respiration and ammonia excretion rates of the Antarctic krill, Euphausia superba Dana. Trans. Tokyo Univ. Fish. 5: 177-187

Stepnik, R. (1982). All year populational studies of Euphausiacea (Crustacea) in the Admiralty Bay (King George Island, South Shetland Islands, Antarctica). Pol. Polar Res. 3: 49-68

Stretch, J. J., Hamner, P. P., Hamner, W. M., Michel, W. C., Cook, J., Sullivan, C. W. (1988). Foraging behavior of antarctic krill Euphausia superba on sea ice microalgae. Mar. Ecol. Prog. Ser. 44: 131-139

Strickland, J. D. H., Parsons, T. R. (1972). A practical handbook of seawater analysis, 2nd edn. Bull. Fish. Res. Bd Can. 167

This article was submitted to the editor
Tande, K. (1982). Ecological investigations on the zooplankton community of Balsfjorden, northern Norway: generation cycles, and variations in body weight and body content of carbon and nitrogen related to overwintering and reproduction in the copepod Calanus finmarchicus (Gunnerus). J. exp. mar. Biol. Ecol. 62: 129-142

Zhou, M., Nordhausen, W., Huntley, M. E. (in press). ADCP measurements of the distribution and abundance of euphausiids near the Antarctic Peninsula in winter. Deep Sea Res.

Zwally, H. J., Comiso, J. C., Parkinson, C. L., Campbell, W. J., Carsey, F. D., Gloerson, P. (1983). Antarctic sea ice 1973-76: satellite passive microwave observations. Report SP-459, NASA, Scientific and Technical Branch, Washington, $\mathrm{DC}$

Manuscript first received: July 27, 1993

Revised version accepted: January 13, 1994 